148/3, 255-272., Budapest, 2018

DOI: 10.23928/foldt.kozl.2018.148.3.255

\title{
Középsố-miocén sziláscet (Cetacea: Mysticeti) humerusok a Pécs, danitzpusztai homokbányából
}

\author{
CSERPÁK Ferenc \\ H-1048 Budapest, Sárpatak u. 7. IV/12., cserpakfeca@gmail.com
}

\section{Middle Miocene whale (Cetacea: Mysticeti) humeri from the Danitzpuszta sand pit, near Pécs}

Abstract

As a result of specimen-gathering in a single locality over the past twenty years, a large number of whale humeri have been collected. These humeri were found in a sand pit at Danitpuszta (near the city of Pecs), in Pannonian sand beds. They appear to have their origins in the Middle Miocene (Sarmatian, Badenian?).

Altogether 19 fossil humeri from the locality have been studied. All of them, except 2 bones, are at present kept in museum collections. They can be classified into three taxa: cf. Cetotherium priscum (EICHWALD 1840); "Cetotherium" aff. maicopicum (SPASSKI 1951), and Cetotheriidae indet.

Fossil humeri have also been found at Pécs-Vasas, Samobor (Croatia), and the Vienna Basin (three specimens). These specimens belong to the same taxon as the humeri of those collected in Danitzpuszta and have been classified into cf. $C$. priscum.

Humeri classified into the whale species cf. Cetotherium priscum (EICHWALD 1840) are the most frequent amongst the finds at Danitzpuszta (as they are in the Carpathian region); these remains have greatly expanded our knowledge of the size and morphological variations of the species.

Although the fossil humeri of "Cetotherium" aff. maicopicum (SPASSKI 1951) are smaller in size than those of the "Cetotherium" maicopicum (SPASSKI 1951) described from the Eastern Paratethys, they show morphological similarities with the latter; therefore, they are likely to be the representatives of a new species belonging to this genus.

Considering morphological and metric characteristics, the author could not find similarities between the small-sized humerus classified as Cetotheriidae indet. and that of other, known taxa; therefore, it is likely to represent a new taxon.

Keywords: Mysticeti, humerus, Pécs, Danitzpuszta, Pannonian Basin, Miocene

Összefoglalás

Az utóbbi húsz év gyújtéseinek köszönhetően nagy mennyiségû sziláscet felkarcsont került elő egyetlen lelőhelyről, a Pécs melletti danitzpusztai homokbányából. A vizsgált humerusok a középső-miocénből (szarmata, badeni?) áthalmozottan, a pannóniai homokban találhatók.

A területről összesen $19 \mathrm{db}$ — kettő kivételével — közgyújteményben elhelyezett humerust tanulmányoztam, melyek három taxonba sorolhatóak: cf. Cetotherium priscum (EICHWALD 1840); „Cetotherium” aff. maicopicum (SPASSKI 1951); és Cetotheriidae indet.

A danitzpusztai cf. C. priscumba sorolt felkarcsontokkal azonos taxont képviselnek a Pécs-Vasasról, a horvátországi Samoborról származó leletek, valamint a Bécsi-medence anyagából előkerült három példány.

A , Cetotherium” aff. maicopicum (SPASSKI 1951) egyedei méreteikben ugyan kisebbek, de morfológiai jellegeikben a Keleti-Paratethysből leírt „Cetotherium” maicopicum (SPASSKI 1951) felkarjával mutatnak nagyfokú egyezést, így azok feltehetően a genushoz tartozó új faj tagjai lehetnek.

A Cetotheriidae indet.-be sorolt kisméretú humerusnak nem sikerült megtalálni morfológiai és metrikus karaktereiben a párhuzamait, így nagy valószínúséggel egy új taxont képvisel.

Tárgyszavak: Mysticeti, humerus, Pécs, Danitzpuszta, Pannon-medence, miocén 


\section{Bevezetés, előzmények}

A Pécs, danitzpusztai homokbánya rendkívül gazdag gerinces ősmaradványokban. A területen megtalálhatóak a homok lerakódásával közel egykorú szárazföldi és édesvízi, valamint az áthalmozott idősebb, badeni-szarmata tengeri faunák (KAZÁr et al. 2007). A tengeri emlősöket a tengeri tehenek (borda, csigolya), a fókák (csigolya, végtagcsontok, medence), és nem utolsó sorban a cetek (karcsontok: felkarcsont, orsócsont, singcsont; csigolya; és a ritkább craniális anyag: perioticum, tympanicum, fogak, koponya és állkapocs elemek) maradványai képviselik (KAZÁR et al. 2007).

A lelőhelyen az áthalmozódás miatt csak izolált csontelemek fordulnak elő, melyek erősen koptatottak, erodáltak, így teljes vagy részleges csontváz előkerülése nem várható. A csontokon sokszor sérülések, törések keletkeztek a bányászat során.

Danitzpusztán minden kétséget kizáróan a szarmata tenger fogascetjeit lehet kimutatni, a badeniből Odontoceti leletet csak valószínúsíteni lehet (KAZÁR 2003, 2005, 2006b, 2010). A tengeri tehenek (Sirenia), a porcoshalak (cápa, rája), valamint a korallmaradványok valószínúleg idôsebbek, badeni korúak lehetnek (KAZÁR 2003). Mivel lehetséges a badeni tengeri fauna jelenléte a leletegyüttesben, így két sziláscet humerus taxon esetében (,Cetotherium" aff. maicopicum, és a cf. Cetotheriidae indet.) a badeniből való áthalmozódás sem zárható ki.

A mecseki lelőhelyek elsô irodalmi említése KRETzOI Miklóstól (1955) származik: „A pécsi pannóniai homokból átmosva két delfin faj (Acrodelphis) és egy valódi bálna (Balaenida) végtagcsont-maradványait találták." A mecseki lelőhelyek gyarapodó anyagának feldolgozása az 1990-es évek végéig nem kezdődött el. Irodalmi áttekintésük KoRDOS 1978, 1992; KoRDOS \& SOLT 1984 tanulmányaiban olvasható. Kutatásaikkal mód nyílt az egyes miocén üledékciklusok faunakülönbségeinek felvázolására. A kutatások új fejezete indult meg, amikor előkerült Kovácsszénájáról egy új delfinfaj csontváza, és a danitzpusztai homokbányából ismertté vált — a magángyưjtők segítő közremúködése által — több ezer begyújtött csontlelet. Feldolgozásukat KAZÁr Emese végezte, aki a doktori disszertációja témájához választotta a Pannon-medence, ezen belül a mecseki fogascetek (Odontoceti) addig ismert anyagát (KAZÁr 2003). A sziláscetek közül Cetotheriidae maradványokat valószínúsített a danitzpusztai lelőhelyrôl (KAZÁR 2003, KAZÁR et al. 2007). Később több tanulmánya is megjelent a Pannon-medence, és a KeletiParatethys fogascetjeiről, melyek rendszertani és ősállatföldrajzi szempontból szintén köthetőek a mecseki lelőhelyekhez (KAZÁR \& VENCZEL 2003; KAZÁR et al. 2004; KAZÁR \& GRIGORESCU 2005; KAZÁr 2005, 2006a, b, 2010).

Danitzpusztán a Mysticeti leletek az összes Cetacea leletanyagnak kb. a 7\%-át teszik ki, melynek nagy része csigolya. Az előkerült nagy mennyiségú csigolyamaradvány (egy-két méretesebb darab kivételével) is jól mutatja, hogy a lelőhelyen egykor igen apró méretű bálnák éltek. Több juvenilis humerus diaphysis, és proximalis epiphysis is ismert az MBFSZ (Magyar Bányászati és Földtani
Szolgálat) gyưjteményében, valamint a szerző magángyưjteményében egyaránt, köztük nagyon fiatal (Foetus, Neonatus) egyedek (pl. MÁFI V.23335, jobb humerus diaphysis; Dp404 — a szerzô magángyújteményének egyedi azonosítója - bal humerus diaphysis). A besorolásuk a három elkülönített taxonba nem lehetséges, a morfológiai jegyek hiányossága miatt. Ontogenetikusan fiatal fázisát mutatják a felkarcsontoknak.

A Pannon-medence és a Keleti-Paratethys tengeri összeköttetését a szarmatában több lelet is bizonyítja, pl. egy fogascet, a Pachyacanthus suessii BRANDT, 1871, amely a Középső-Paratethys területéról valamint a Kaukázusból is előkerült (DOMBROVSKIJ 1927; HÁMOR 2001; KAZÁR 2003, 2010).

A Középsô-, és a Keleti-Paratethys sziláscetleletei mellett tanulmányozásra kerültek további lelőhelyek maradványai is. A Földközi-tenger régiójából nem ismert humerussal is rendelkező középső-miocén sziláscet-előfordulás. Belgium környékéról (VAN BENEDEN 1882, 1885, 1886), és Észak-Amerika területérôl (KellogG 1929, 1931, 1965, 1966, 1968, 1969; PACKARD \& KELlOGG 1934; DoOLEY et al. 2004), írtak le több humerussal is rendelkező, de nagyobb méretű Mysticetiket. Dél-Amerikából, Peru környéki lelőhelyekről PILLERI (1989), BouETEL \& MuIzon (2006) közöl szintén nagyobb méretû, pliocén előfordulású leleteket. Ezek a felkarok jóval nagyobbak, robusztusabbak a danitzpusztai példányoknál, és amellett anatómiailag is igen eltérőek, így e csontokkal történő összevetéstől itt eltekintek.

Jelen tanulmány a danitzpusztai sziláscet felkarcsontok taxonómiai vizsgálatával foglalkozik, azokról részletes anatómiai leírást közöl, metrikus adatokkal, fotótáblákkal. A tanulmány célja felhívni a figyelmet a humerusok diagnosztikai jelentőségére, hogy a mecseki gazdag előfordulásuk értékes adalékként szolgálhasson más területekrôl előkerülő Mysticeti leletek vizsgálatához.

\section{A lelóhely földtani ismertetése}

A Pécs, danitzpusztai homokbánya - egykori nevén Lauber-homokbánya (Pécsváradi út 1. sz. homokbánya; Pécs, Laktanya melletti homokbánya) — a város keleti peremén, a laktanya szomszédságában (a 6-os múút északi oldalán) helyezkedik el (földrajzi koordinátái: 4606'03.37'É, $18^{\circ} 17^{\prime}$ '05.39'’K).

A danitzpusztai homokbánya közel 100 éve tanulmányozott, klasszikus feltárása a pannóniai korszakban zajlott szerkezeti mozgásoknak (KAZÁR et al. 2007, KonRÁd et al. 2010). A bánya feltárásának képe a múvelés miatt folyamatosan változik.

A bányában vizsgálható képződmények a Pannon-medence nagy részét elborító, csökkent sós vizú Pannon-tóban rakódtak le, melyből a Mecsek szigetként emelkedett ki (Konrád et al. 2010, MaGYAR 2010).

A congeriás, lymnocardiumos, fehér márgára a badeni és szarmata korszakból áthalmozódott gerinces állatok maradványaival, sárga, limonitos homok települ (HÁMOR 
1981, KAZÁR et al. 2007, KonRÁD \& SEBE 2010, KonRÁD et al. 2010, MAGYAR 2010). A bányászott homok és kavics anyaga a környezô területek idős kőzeteinek lepusztulásából, valamint a fiatalabb miocén korú üledékekből tevődik össze, mely utóbbiak a bennük található ősmaradványokkal együtt halmozódtak át (KAZÁR 2003, KAZÁR et al. 2007, KONRÁD et al. 2010). A mollusca-biosztratigráfia alapján az öszlet kora 11-10 millió év (SEBE et al. 2015).

\section{Anyag és módszer}

A latin terminusok használata (1. ábra), valamint a metrikus (2. ábra) és morfológiai karakterek kijelölése az alábbi szerzők múvei felhasználásával készült: BÄUML 1933, Pia 1937, BEnKe 1993, KaZÁr 2003, KAZÁr \& BOHASKA 2008.

Az összehasonlítandó példányok vizsgálatai —a Mesocetus hungaricus, és a Pécs-Vasasról előkerült felkarcsont kivételével - melyek a hazai közgyújteményekben tanul-

a

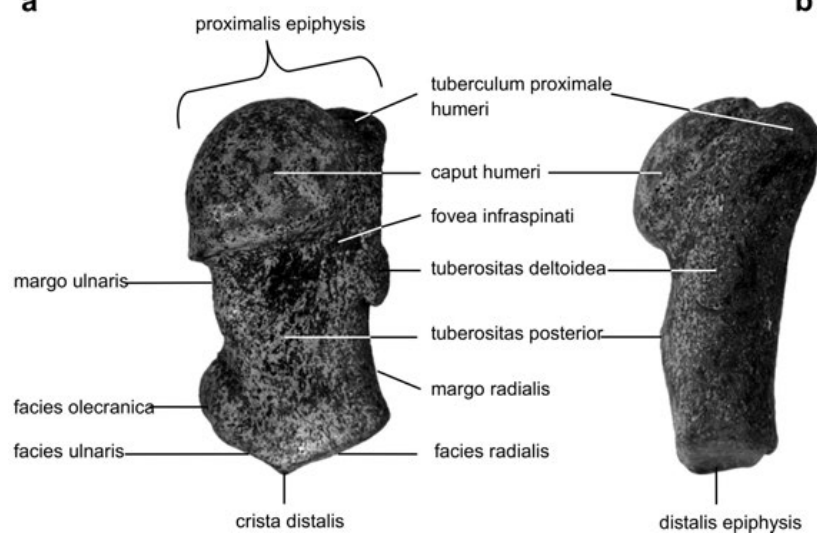

1. ábra. A humerus anatómiai megnevezései. Mysticeti jobb humerus, (a) lateralis és (b) anterior nézetben

Figure 1. Anatomical terms for the humerus. (a) lateral and (b) anterior views of the right humerus of a whale belonging to the Mysticeti

mányozhatóak voltak — a korabeli leírások, ábrázolások felhasználásával történtek. További segítséget jelentett HAMPE (1996) munkája, aki szintén vizsgálatokat végzett Mysticeti humerusokon, ismertetve az addig előkerült fontosabb példányokat.

A vizsgálatokat nehezítette, hogy több szerző is tévesen, anatómiailag felcserélve - lateralis (oldalnézet) helyett, medialis nézetból — ábrázolta és írta le humerusleletét.

Az MBFSZ-ben elhelyezett felkarcsontok egy, még ezidáig tisztázatlan része, visszakerül a magángyưjtőkhöz, így azoknak csak a gipszmásolatát lehet közgyưjteményben tanulmányozni. A mérések minden esetben az eredeti példányokon készültek.

A cf. Cetotherium priscum taxonhoz sorolt felkarcsontok jelentős része két leltári számmal (régi és az új) rendelkezik, így a tanulmányban mindkettő feltüntetésre került.

A vizsgált anyag, (19 db) két darab kivételével, az MBFSZ Gyưjteményi Osztály gerinces gyưjteményében a
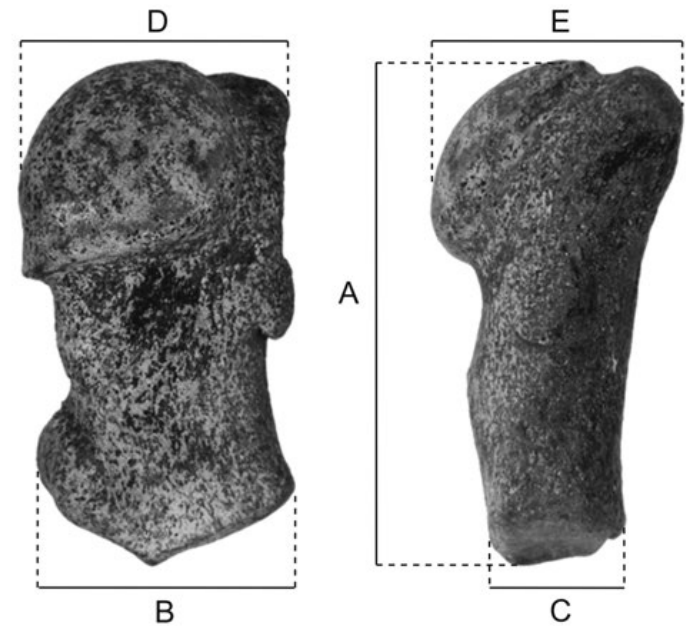

2. ábra. A humerus mérőpontjai. Mysticeti jobb humerus (a) lateralis és (b) anterior nézetben. A: teljes hossz: a crista distalis és a caput humeri proximalis része közötti kiterjedés; B: a diaphysis distalis részének antero-posterior kiterjedése; $\mathrm{C}$ : a diaphysis distalis részének medio-lateralis kiterjedése a crista distalisnál; D: proximalis epiphysis antero-posterior kiterjedése; E: proximalis epiphysis medio-lateralis kiterjedése

Figure 2. Measuring points of the humerus. (a) lateral and (b) anterior views of the right humerus of a whale belonging to the Mysticeti. A: total length: distance between the proximal part of the caput humeri and the crista distalis; $B$ : anteroposterior extension of the distal part of the diaphysis; $C$ : mediolateral extension of the distal part of the diaphysis at the crista distalis; $D$ : anteroposterior extension of the proximal epiphysis; E: mediolateral extension of the proximal epiphysis

van elhelyezve részben eredeti, részben gipszmásolat formájában.

\section{A danitzpusztai példányok leírása}

Cetacea BRISSON, 1762

Mysticeti COPE, 1891

Cetotheriidae BRANDT, 1872

Cetotherium BRANDT, 1843

\section{cf. Cetotherium priscum EICHWALD, 1840}

(1-2. ábra; I. táblázat; I-V. tábla, és VII. tábla: 2.)

Pécs, Danitzpusztán a legnagyobb egyedszámban megjelenô taxon. Az alábbi példányok sorolhatóak ebbe a típusba: I-V. tábla, és VII. tábla: 2, valamint az I. táblázat: 1-16. A vizsgált anyagban csak két fiatal bálna humerusa található (I. táblázat: 3 és 16), az összes többi példány kifejlett egyedhez tartozik.

A humerus tömzsi, a három típus közül a legnagyobb. A legkeskenyebb pontja lateralis nézetból a tuberositas deltoidea ventralis kiterjedése alatt mérhetô, ami egyes esetekben a teljes humerus, (pl. I. táblázat: 8) vagy ettől eltérốn a diaphysis középmagasságában (pl. I. táblázat: 7) található. A diaphysis a legkeskenyebb ponttól proximalisan és distalisan is kiszélesedik. A caput humeri dorsalisan nézve félgömb alakú, proximo-distalis kiterjedése a megfelelő megtartású példányokon átlag 1/3 része a teljes hossznak. A 
I. táblázat. A danitzpusztai Mysticeti humerusok metrikus adatai (mm-ben, $\pm 0,5 \mathrm{~mm}$ )

Table I. Metric data of Mysticeti humeri derived from Danitzpuszta (in $\mathrm{mm}, \pm 0,5 \mathrm{~mm}$ )

\begin{tabular}{|c|c|c|c|c|c|c|}
\hline Num. & & A & B & $\mathrm{C}$ & D & $\mathbf{E}$ \\
\hline \multicolumn{7}{|c|}{ cf. Cetotherium priscum EICHWALD, 1840} \\
\hline 1 & MÁFI V.23218 distalis fragmentum, dext. & 78,4 & $50,1+$ & 24,5 & - & - \\
\hline 2 & MÁFI V.23219, I. tábla: 2 , dext. & 114,5 & $47,0+$ & 20,9 & $58,7+$ & $48,4+$ \\
\hline 3 & MÁFI V.24197 diaphysis, II. tábla: 2a-b, dext. & 86,6 & 51,0 & 26,6 & $49,7+$ & $41,6^{+}$ \\
\hline 4 & MÁFI V.09.274.1, (MÁFI V.28723), II. tábla: 1a-d, dext. & 110,6 & 49,4 & 22,1 & $53,5^{+}$ & $49,0^{+}$ \\
\hline 5 & $\begin{array}{l}\text { MÁFI V.09.313.1, (MÁFI V.28762), proximalis fragmentum, } \\
\text { VII. tábla: 2, dext. }\end{array}$ & 95,1 & - & - & $50,2+$ & $40,4+$ \\
\hline 6 & MÁFI V.09.315.1, (MÁFI V.28764), V. tábla: 1a-c, dext. & 132,5 & 65,6 & 28,0 & $62,0^{+}$ & $61,5+$ \\
\hline 7 & MÁFI V.09.316.1, (MÁFI V.28765), IV. tábla: 2a-b, dext. & 133,6 & 61,3 & 30,2 & - & - \\
\hline 8 & MÁFI V.09.317.1, (MÁFI V.28766), III. tábla: 2a-c, sin. & 130,5 & 62,4 & 27,0 & $65,0^{+}$ & $59,5+$ \\
\hline 9 & MÁFI V.09.318.1, (MÁFI V.28767), distalis fragmentum, sin. & 105,0 & 65,0 & 30,0 & - & - \\
\hline 10 & MÁFI V.09.319.1, (MÁFI V.28768), I. tábla: la-f, dext. & 117,2 & 54,3 & 24,3 & 62,8 & 54,5 \\
\hline 11 & MÁFI V.09.320.1, (MÁFI V.28769), distalis fragmentum, dext. & 94,5 & 58,6 & 29,9 & - & - \\
\hline 12 & $\begin{array}{l}\text { MÁFI V.09.321.1, (MÁFI V.28770), distalis fragmentum, IV. } \\
\text { tábla: 3, dext. }\end{array}$ & 109,0 & 62,7 & 30,0 & - & - \\
\hline 13 & MÁFI V.09.322.1, (MÁFI V.28771), III. tábla: la-c, sin. & 146,2 & $67,5^{+}$ & 33,7 & - & $68,0^{+}$ \\
\hline 14 & MÁFI V.09.323.1, (MÁFI V.28772), V. tábla: 2, dext. & 120,7 & 49,0 & 23,4 & $60,3+$ & 46,7 \\
\hline 15 & Dp.379, IV. tábla: 1a-c, sin. & 140,2 & 61,5 & 32,0 & $73,0^{+}$ & $64,0^{+}$ \\
\hline 16 & Dp.2640 diaphysis, V. tábla: 3a-e, sin. & 70,7 & 40,0 & 20,2 & 43,7 & 35,5 \\
\hline \multicolumn{7}{|c|}{ „Cetotherium” aff. maicopicum } \\
\hline 17 & MÁFI V.23216, VI. tábla: 2, dext. & 85,7 & - & $16^{+}$ & - & - \\
\hline 18 & MÁFI V.23217, VI. tábla: 1a-f, sin. & 85,5 & 37,4 & 18,1 & - & $39,0^{+}$ \\
\hline \multicolumn{7}{|c|}{$\begin{array}{c}\text { Cetotheriidae indet. } \\
\end{array}$} \\
\hline 19 & MÁFI V.24188, VII. tábla: la-f, dext. & 94,4 & 48,9 & 23,8 & 52,7 & 47,4 \\
\hline
\end{tabular}

Jelen állapotában mérhető kiterjedés enyhén sérült példánynál (a szám után: „„”). Jelentős sérülés esetén nincs adat. A humerus mérőpontjai a 2. ábra alapján lettek kijelölve. A két diaphysisnél a mérőpontok a diaphysis proximo-distalis (A) kiterjedése, és a proximalis és distalis ízesülési felületek, antero-posterior (B, $\mathrm{D})$, medio-lateralis $(\mathrm{C}, \mathrm{E})$ kiterjedésére vonatkoznak. A fragmentumok esetében az „A” érték a proximo-distalisan mérhető legnagyobb kiterjedés.

The present state of measurable extension on a slightly injured specimen ("+" after numbers). In case of significant damages no data are available. Measuring points of the humeri see in Figure 2. Considering the two diaphyses, the measuring points refer to the proximo-distal (A) extension of the diaphysis, and antero-posterior (B, D), mediolateral $(C, E)$ extension of the proximal and distal articulation surface. In case of the fragments, value "A" is the largest proximo-distal range on humeri

humerus proximalisan legmagasabb pontja a tuberculum proximale humeri (I. táblázat: 2, 6, 8, 13), vagy a caput humeri (I. táblázat: 10 és 15). A többi darabon a tuberculum proximale humeri kiterjedése az erodáltság és a recens sérülések miatt nem tanulmányozható. Valamint minden esetben, amikor a tuberculum proximale humeri a humerus legmagasabb pontja, annak pontos proximalis kiterjedése a példányok sérüléséból adódóan nem állapítható meg ( $I$. táblázat: 2, 6, 8, 13). A tuberositas deltoidea a koptatott példányok kivételével erôteljes kiemelkedés a margo anterioron (margo radialison), elkülönül a tuberculum proximale humeritől, dorso-ventralisan kiterjedt, általában centrális (pl. I. táblázat: 10), néhány kivétellel a középmagasságtól proximalis (pl. I. táblázat: 8) helyzetû. A fovea infraspinati nagy felületú, határozott bemélyedés a humerus középvonalától anterior helyzetben, a caput humeri alatt. A tuberositas posterior a diaphysis középmagasságában található sekély, ovális benyomat formájában — kifejezettsége a koptatottság mértékéből adódóan lehet eltérô. A distalis epiphysisen a facies radialis kiterjedése meghaladja a facies ulnaris kiterjedését, így a crista distalis a humerus hossztengelyétôl posterior irányban található. A facies olecranica az ulna fejlett processus olecranicajának megfelelően mindig jellemző, és néhány esetben a humerus és az ulna összecsontosodásának jelei is megfigyelhetőek (pl. I. táblázat:
7). Az anyag méret szerint két részre osztható (átfedés nélkül) a morfológiai tulajdonságok lényeges eltérése nélkül, aminek oka lehet az ivari dimorfizmus, esetleg a nagy intraspecifikus variáció is. Az anatómiai jegyek kisebb mértékú eltérését néhány esetben paleopathológiai elváltozások okozzák. A felkarcsontok méretei alapján a taxonhoz tartozó bálnák testhossza kb. 2,5-3,5 m között lehetett.

Összehasonlitás a Középsó- és a Keleti-Paratethys területéról elókerült leletekkel: A Cetotherium genust BRANDT (1843) vezette be a Cetotherium rathkii leírásakor, amely nembe a Ziphius priscust is bevonta, amit EICHWALD eredetileg csőröscetnek tartott. A Cetotherium priscum EICHWALD, 1840 (BRANDT 1843, 1872a, b, 1873; NORDMANN 1860), - vagy korábbi elnevezéssel Ziphius priscus (EICHWALD 1840, 1853) - fajt EICHWALD mandibula töredék, borda, és csigolyák alapján írta le a Krím-félsziget szarmata rétegeiből, mely csontelemek faji szintú leírásának megalapozottsága vitatható, de megfelelt az akkori gyakorlatnak. Később humerust is soroltak a taxonhoz, egyet EichWALD (1853), és ehhez még kettőt BRANDT (1873). A nagyfokú méretbeli és anatómiai hasonlóság miatt, - még, ha e faj helye taxonómiailag nem tisztázott is — valószínúleg ehhez tartozik a danitzpusztai anyagból 16 példány. 


\section{A Középső-Paratethys szarmata korú leleteinek összehasonlítása és revíziója}

Danitzpusztán kívül, a mai Magyarország területérôl csak a közeli Pécs-Vasasról ismert egy sziláscet (Mysticeti indet.) humerus (MÁFI V.18393/4, jobb humerus). A taxon az anatómiai és méretbeli jegyeik alapján a cf. $C$. priscum fajhoz tartozik. A Pécs-Vasason az 1990-es évek első felében gyújtött leletegyüttes pontos elókerülési helye nem ismert, de valószínúleg a 6-os múút déli oldalán, a vasasi útelágazásnál fekvő egykori bányából (valószínúleg szarmata rétegekből áthalmozódva) származik (KAZÁr 2003).

Egy, még korábban juvenilis fogascetnek tartott leletet BRANDT (1873) közölt Bécs-Hernals szarmata rétegéből (NHMW: Naturhistorisches Museum Wien 1853, II. 8-13. leltári számon) Delphinus (?) brachyspondylus néven, amit egy évvel később Macrochirifer vindobonensisre változtatott (BRANDT 1874). Ezt a humerust BÄUML (1933) is közölte dolgozatában, de már sziláscet maradványának tartotta. Később PIA \& SicKENBERG (1934) egy másik leletegyüttest említett „Cetotherium” sp. néven Bécs-Heiligenstadt szarmata rétegéből „NHMW 1895, 66” leltári számon, amit PIA (1937) a BRANDT (1873) által leírt lelettel együtt a Mysticetibe sorolt, és nevét Mesocetus (?) brachyspondylusra változtatta. A PIA (1937) által ábrázolt felkarcsont nem teljes, a caput humeriból és a tuberculum proximale humeriből is hiányzik egy darab. De mindezek ellenére világosan látható a morfológiai, és a kisebb példányokkal való méretbeli egyezése, a danitzpusztai cf. C. priscum taxonba sorolt példányokkal. BRANDT (1873) által leírt és ábrázolt juvenilis humerus méretben és morfológiában is megegyezik a MÁFI V.24197 leltári számú jobb humerus diaphysis (II. tábla: 2a-b) példányával. A PIA (1937) által leírt és ábrázolt jobb humerus anatómiailag szintén a fajhoz sorolható (pl. I. táblázat: 4, II. tábla: $1 a-d$ ).

Ismert egy szintén a Bécsi-medencéből származó szarmata korú példány (KAZÁR Emese szóbeli közlése), pontos lelőhely megjelölése nélkül (NHMW 1874 V.29. leltári számon), amit viszont PIA \& SiCKENBERG (1934) nem említett katalógusában. Ez a bal humerus morfológiai jellegeiben és méretében is teljesen megegyezik a danitzpusztai taxonnal (pl. 1. táblázat: 8, III. tábla: $2 a-c$ ).

A mai Horvátország területéről, GoRJANOvićKRAMBERGER (1884) közölt két humerusleletet. Az egyik a Mesocetus agrami VAN BENEDEN, 1882 felkarcsontja Podsusedról, a másik a Cetotherium cf. priscum Samoborról (HPM: Hrvatski Prirodoslovni Muzej 1.184/25. lelt. számon), mindkettő szarmata rétegből. A Mesocetus agramiba sorolt humerus méretében és morfológiai bélyegeiben is eltér - nagyobb, robusztusabb - a danitzpusztai példányoktól, viszont a szamobori $C$. cf. priscumként leírt felkarcsont a danitzpusztaiakkal teljesen megegyezik.

A szlovéniai Benediktről a közelmúlban publikálták a Balaenoptera acutorostrata cuvierii (BALSAMO-CRIVELLI, 1842) alfajba sorolt szarmata korú, juvenilis csontvázat (PAVŠIČ \& MikUŽ 1996). Az ábrák alapján a humerus preparálatlan, a proximalis epiphysis a rétegnyomás következtében elmozdultan ôrződött meg, így az anatómiai karak- terek nehezen tanulmányozhatóak. A leírás szerint méret alapján beilleszthető a danitzpusztai cf. C. priscum kisebb példányaihoz, így nem zárható ki, hogy ugyanabba a taxonba sorolhatóak. Ismereteinket nagyban bővítené a szlovéniai csontváz, ha bebizonyosodna az egyezése a danitzpusztai taxonnal, mert a karcsontok mellett megôrzôdött a koponyája is. Sajnos a publikációban közölt táblák nem alkalmasak a felkarcsont részletesebb tanulmányozására. A bálnacsontváz felkarjának a megtartási állapota miatt, pontos taxonómiai összehasonlításokat csak a vázrész személyes vizsgálata után lehet tenni.

Egy szintén Cetotherium priscum EichwaLd, 1840 fajhoz sorolt humerus Bulgáriából (Dobrogea) Balcic szarmata lelőhelyéről származik (SIMIONESCU 1931). Az ábrázolásból kitúnik, hogy a caput, és a tuberculum proximale humeri nagy része hiányzik. A vizsgálható méretbeli adatok alapján, a danitzpusztai nagyobb példányokkal mutat egyezést. A morfológiai bélyegek a sematikus ábrázolás miatt, nem vethetőek össze a danitzpusztai taxonnal. Így a SiMIONESCU (1931) által a Cetotherium priscum fajhoz sorolt felkarcsontról nem állapítható meg, hogy az egy taxonba tartozik-e a danitzpusztaival.

\section{A Középső-Paratethys badeni korú leletei}

A Bécsi-medence (Borbolya) középső-badeni rétegéből egy juvenilis bálna, a Mesocetus hungaricus teljes csontvázát KADIČ (1907) írta le. Mindkét felkarcsontja ismert, amit a csontváz egyéb részei mellett tanulmányozni lehetett. A csontváz a Magyar Természettudományi Múzeum gyưjteményében található MTM V.79.118 leltári szám alatt. KADIČ leírásában felcserélve, oldalhibásan ábrázolta és írta le a két karcsontot, így a bal oldali van jobb megtartásban. A humerusokat több darabból illesztették össze, a hiányzó részeket gipsszel pótolták. A danitzpusztai példányok sokkal kisebb fajt képviselnek, mint a Mesocetus hungaricus, azoktól egyértelmúen elkülöníthetô morfológiailag, és a nagy méretkülönbség miatt.

BRANDT (1873) a szentmargitbányai lajtamészkőbányából publikált egy (NHMW:1866, I, 24. leltári számon) $C$. priscum bal humerust, amit PIA \& SicKENBERG (1934) fosszilis emlőskatalógusában ismét közöltek „Cetotherium priscum" BRANDT néven. PIA (1937) írta le és ábrázolta ugyanezt a badeni leletet Balaenida (?) „Cetotherium priscum" elnevezéssel. Az ábra alapján a humerus distalis részéből, és a tuberculum proximale humeriből is hiányzik egy kis darab. A lateralis nézetból ábrázolt humerus néhány karakterében hasonlít a cf. C. priscumba sorolt egyedekhez, de különbségként kiemelhető a caput humeri nagyobb mérete, és a tuberositas deltoidea fejlettebb kiterjedése. A példány valószínúleg azonos genushoz tartozik a danitzpusztaival, de más fajt képvisel.

A ,Cethotherium aff. rathkei VAN BENEDEN, 1868-1880” néven leírt szintén juvenilis részleges csontváz Boszniából (Stribči) származik, badeni korú rétegból (STEFANOVIĆ 2010). A publikációban oldalhibásan, anatómiailag tévesen, megcserélve leírt és ábrázolt két humerus (RGFC 6-7. leltári számon) diaphysis, méretben és morfológiailag hasonlóságot mutatnak a kisebbik danitzpusztai juvenilis példánnyal 
(Dp.2640, V. tábla: 3a-e). Mivel mindkét felkarcsont fiatal, nem teljesen kifejlett egyedtől származik, a morfológiai tulajdonságaik kevésbé jellegzetesek, így a példányokat azonos taxonba besorolni nem lehet.

A Pinocetus polonicus CzYŽEWSKA \& RYZIEWICZ (1976) lengyelországi (Piǹczów) badeni felkarcsont is a nagy méretbeli különbségek, illetve eltérő morfológiája miatt mutat határozott különbségeket.

\section{Revízió és megjegyzések}

A Középső-Paratethys területérôl több sziláscet csontváza vagy izolált csonteleme is előkerült, amelyek között a taxon meghatározásához alkalmas humerus is megtalálható. Ezek a középső-miocén badeni vagy szarmata - esetenként e kettő korból áthalmozottan fiatalabb — rétegekből kerülttek elő.

A cf. Cetotherium priscum taxonba sorolt felkarcsontok más Pannon-medencei, egyértelmúen e fajhoz tartozó leleteik alapján szarmata korúak (BRANDT 1873, GORJANOVIĆKramberger 1884, Pia \& Sickenberg 1934, Pia 1937).

A danitzpusztai cf. Cetotherium priscummal azonos taxonba tartoznak a Pécs-Vasas, a Bécs-Hernals, a BécsHeiligenstadt, a pontos lelőhely nélküli bécsi-medencei, valamint a horvátországi Samoborról származó felkarcsontok.

\section{A Keleti-Paratethys szarmata korú leletei}

A Cetotherium klinderi BRANDT, 1871 jobb oldali juvenilis humerusát a moldáviai Chisinauból, középső-szarmata rétegből, BRANDT (1873) medialis irányból ábrázolta, így a tuberositas posterior és a fovea infraspinati nem vizsgálható. Ez alapján a diaphysis és a proximalis epiphysis maradt meg, a distalis epiphysis hiányzik. A proximalis epiphysist a rajzoló nem illesztette a pontos helyére, így azt a benyomást kelti, hogy nem tartoznak össze. A mérete néhány danitzpusztai cf. C. priscumba sorolt példányhoz hasonló, de eltérésként kiemelhető, hogy a legkeskenyebb pontja medialisan az alsó harmadában közvetlenül a facies olecranica felett mérhető. További különbség, hogy proximalisan és distalisan is erőteljesen ,szoknyaszerúen” kiszélesedik. Az anatómiai bélyegek alapján, egyértelmúen elkülöníthető a danitzpusztai taxontól.

A Cetotherium rathkii BRANDT, 1843 jobb oldali humerus proximalis fragmentuma — az ukrajnai Kercs késôszarmata rétegeiből — (BRANDT 1873), különbözik abban, hogy a tuberculum proximale humeri anterior kiterjedtsége jóval kisebb, alakja erősen csúcsosodó. Mérete alapján a nagyobb egyedekhez hasonlítható, ahol a tuberculum proximale humeri a felkar legmagasabb pontja. A morfológiai eltérések miatt nem tartozhat a danitzpusztai taxonhoz.

A Cetotherium riabinini (HofsTEIN, 1948) — az ukrajnai Nikolaev késő-szarmatájából — (GoL’DIN et al. 2014), mindkét juvenilis humerusa ismert (tévesen felcserélve anatómiailag, lateralis nézet helyett medialisan ábrázolják és illesztették a felkarokat a csontvázra) mérete alapján ugyan hasonló a $C$. priscumhoz, de különbség, hogy a diaphysis antero-posterior irányban szélesebb, a tuberculum proximale humeri kevésbé kiterjedt, és a facies olecranica dorsalisan feljebb húzódik a margo ulnarison. A hibás ábrázolás miatt a fovea infraspinati és a tuberositas posterior helyzete nem tanulmányozható. Ezek alapján más fajt képvisel, mint a danitzpusztai taxon.

A Mithridatocetus (Cetotherium) mayeri (BRANDT, 1871) fajba két eltérô morfológiájú humerust soroltak be az idôk folyamán (BRANDT 1873, RIABININ 1934, Mchedlidze 1964, GoL'DIN \& STARTSEV 2016) különböző lelőhelyekről (Kercs, Kuban, Georgia), felsô-szarmata rétegekből. Ezek méretben a legnagyobb danitzpusztai példányhoz hasonlíthatóak (I. táblázat: 13, III. tábla: 1ac). A BRAndT (1873) által közölt $C$. mayeri jobb humerusa, amit GOL'DIN \& STARTSEV (2016) újból ábrázol, továbbá cikkükben egy Cetotheriinae indet. jobb felkarcsontja egy taxonba tartozhat (saját megfigyelés). Különböznek a danitzpusztaiaktól abban, hogy jóval fejlettebb és dorso-ventralisan kiterjedtebb tuberositas deltoidea van jelen, és a humerus legkeskenyebb pontja az alsó harmadánál mérhetô. RIABININ (1934) C. mayeri részleges juvenilis csontvázának humerusai, és a MCHEDLIDZE (1964) C. cf. mayeri felkarjának ábrája már más — melyek véleményem szerint anatómiailag azonosak — morfológiájú példányokat mutat. Ezek alapján a különbséget a caput humeri jóval nagyobb mérete, a humerus proximalisan szélesebb kiterjedése, de kisebb méretú tuberculum proximale humeri adja. Valamint a humerus legkeskenyebb pontja a tuberositas deltoidea alatt jóval kb. a humerus alsó harmadánál mérhető. Mindezek alapján elkülöníthető a danitzpusztai fajtól, ezek a példányok más taxonokat képviselnek.

A Vampalus (Eucetotherium, Cetotherium) helmersenii BRANDT, 1871 Oroszországból (Pekla) középső-szarmata rétegeiből származik. A medialisan ábrázolt — sajnos a lateralis bélyegek így nem láthatóak — bal humerus proximalis fragmentuma különbözik az általam leírt példányoktól abban, hogy a tuberculum proximale humeri kiterjedtebb, csúcsosabb, a diaphysis medialisan vékonyabb (BRANDT 1873, GOL'DIN \& STARTSEV 2014). A vizsgálható anatómiai jegyek alapján elkülöníthető a danitzpusztai taxontól.

Az Otradnocetus virodovi McHEDlidze (1984) Oroszország (Otradnaya) középső-miocén korú rétegéből - bal oldali humerusa alapján eltérés a danitzpusztai példányoktól a nagy mérete, a tuberculum proximale humeri kis kiterjedése, nagy felületú caput humeri valamint, hogy anterior nézetból középmagasságban a diaphysis medialisan meghajlik. Így más taxont képvisel, mint a danitzpusztai cf. Cetotherium priscum fajba sorolt példányok.

A Vampalus sayasanicus TARASENKO \& LOPATIN (2012b) középsô-felső-miocén Csecsenföldről, és a Zygiocetus nartorum TARASENKO (2014) az Észak-Kaukázusból (Adigeföld) középső-szarmata rétegből leírt fajok humerusa is ismert. Sajnos egyik sincs ábrázolva, és a rövid, felületes leírás alapján morfológiailag nem lehet összevetni a danitzpusztai fajjal, azonban metrikusan (I. táblázat: 13, III. tábla: $1 a-c)$ a legnagyobb elókerült humerussal részben megegyezik. 


\section{A Keleti-Paratethys karagan korú lelete}

Az Imerocetus karaganicus MCHEDLIDZE (1964) grúziai karagan (a Középsô-Paratethysben badeni) korú bal humerusa alapján különbség, hogy nagyobb méretû, robusztusabb, a tuberculum proximale humeri kicsi, — bár ez utóbbi adódhat a példány töredezettségéból is, mert azt több darabból állították össze - a facies olecranica kevésbé fejlett. A tanulmányozható bélyegek alapján egyértelmúen más taxont képvisel.

\section{Megjegyzések}

A Keleti-Paratethys területén a badenivel egykorú üledékekből nem ismert fogascet előfordulás (KAZÁR 2003), és a szilásceteket is csak egy faj az Imerocetus karaganicus képviseli (McHEDLIDZE 1964, GoL'DIN \& STARTSEv 2014).

A fent felsorolt szarmata és badeni korú leletek, más taxonokat képviselnek, mint a danitzpusztai cf. Cetotherium priscum. A danitzpusztai fajhoz legközelebb a Cetotherium klinderi BRANDT (1871), és a Cetotherium rathkii BRANDT (1843) felkarjai állnak.

A Vampalus sayasanicus TARASENKO \& LOPATIN (2012b), és a Zygiocetus nartorum TARASENKO (2014) esetében, a humerus ábrázolt megismerése is szükséges lenne a pontosabb összehasonlításhoz.

\section{„, Cetotherium” aff. maicopicum (1-2. ábra; I. táblázat; VI. tábla)}

A vizsgált humerus példányok közül a legkisebb méretûek. A közgyújteményből két példány sorolható a fajba (MÁFI V.23216 jobb humerus, VI. tábla: 2; MÁFI V.23217 bal humerus, VI. tábla: la-f, I. táblázat: 17, 18).

A taxonhoz sorolt humerusok mind kifejlett egyedektől származnak, a diaphysis teljesen összenôtt az epiphysissel. A múzeumban ôrzött két példány közül a MÁFI V.23217 bal humerus a jobb megtartású, de ez a darab is kopott és a tuberculum proximale humeri nagy része hiányzik. Méretéből arányosítható, hogy a bálna testhossza alig haladta meg a kettő métert. A humerus rövid, vékony és szokatlanul kisméretû. A legkeskenyebb pontja lateralis nézetből a diaphysis distalis részén közvetlenül a facies olecranica felett található. A legkeskenyebb ponttól distalisan kis mértékben, proximalisan erősen szélesedik. A caput humeri dorsalis nézetből nagyjából félgömb alakú, lateralis nézetben kis mértékben meghaladja a humerus teljes hosszának 1/3-át. A tuberculum proximale humeri egy részének hiánya miatt annak anterior kiterjedése nem tanulmányozható. Az sem dönthetô el, hogy a tuberculum proximale humeri meghaladja-e a caput humeri proximalis magasságát. A tuberositas deltoidea erôsen erodált, de kivehetô a margo radialison, a humerus középmagasságában, elkülönül a tuberculum proximale humeritől, dorso-ventralisan kiterjedt. A fovea infraspinati jól körülhatárolható bemélyedést alkot és anterior helyzetú a caput humeri alatt. A tuberositas posterior a diaphysis hossztengelyének középmagasságában található és kis bemélyedésként van jelen. A facies radialis antero-posterior kiterjedése nagyobb, mint a facies ulnarisé, így a crista distalis a humerus hossztengelyétől posterior irányban helyezkedik el. A facies olecranica jól mutatja az ulna fejlett processus olecranicájának meglétét.

Összehasonlitás a Keleti-Paratethys területéról elókerült lelettel: A „Cetotherium” aff. maicopicum az összehasonlítások alapján a „Cetotherium” maicopicum SPASSKI, 1951, Keleti-Paratethys területérôl (Oroszország, Adigeföld: Maikop) középsô-szarmata korú rétegből leírt (SPASSKI 1951, 1954; MCHEDLIDZE 1964, 1970; PILLERI 1986) faj humerusával mutat nagyfokú morfológiai egyezést. Méretben ugyan kisebbek a danitzpusztai kifejlett egyedektől származó példányok, de a morfológiai hasonlóság miatt, mint új faj valószínúleg a genushoz tartozhatnak.

A ,Cetotherium” maicopicum fajt TARASENKO \& LOPATIN (2012a), az újonnan felállított Kurdalagonus nemzetséghez sorolta két további taxonnal (K. adygeicus és a $K$. mchedlidzei) együtt. Majd GOL'DIN \& STARTSEV (2016) a Kurdalagonus mchedlidzei fajt elismerve, a K. adygeicus taxont az általuk felállított új Mithridatocetus nemzetséghez vezeti át, és megállapítják, hogy a „Cetotherium” maicopicum taxonómiai besorolása további kutatásokat igényel.

\section{Megjegyzések}

Egyéb, más területekről előkerült humerusoktól, a sajátságos anatómiai bélyegek és a jelentôs méretbeli különbségek alapján egyértelmúen elkülöníthetô a taxon. Új fajként történő leírásához további jó megtartású leletek szükségesek.

A tanulmányozott felkarcsontok, a fogascet-vizsgálatok eredményei alapján (KAZÁr 2003, 2005, 2006b, 2010), valószínúleg szarmata (esetleg badeni) üledékből halmozódtak át.

\section{Cetotheriidae indet.}

\section{(1-2. ábra; I. táblázat; VII. tábla: 1a-f.)}

Közgyújteményben egyetlen jó állapotban megtartott példánya található (MÁFI V.24188 jobb humerus, VII. tábla: 1a-f, I. táblázat: 19).

A kifejlett példánytól származó felkarcsont rövid és tömzsi. A legkeskenyebb pontja a lateralis nézetből a diaphysis distalis részén a facies olecranica felett található. A diaphysis a legkeskenyebb ponttól distalisan és proximalisan is kiszélesedik. A caput humeri viszonylag nagy kiterjedésú, a teljes hossz kb. 45\%-át teszi ki, dorsalisan nagyjából félgömb alakú, posterior oldalán kiemelkedő éllel. A humerus proximalisan legmagasabb pontja a caput humeri. A tuberculum proximale humeri medio-lateralis kiterjedése kisebb, antero-posterior irányban nagyobb. A tuberositas deltoidea jól kivehetô erőteljes kiemelkedés a margo radialison, elkülönül a tuberculum proxomale humeritől, dorso-ventralisan kiterjedt, a humerus középvonalában helyezkedik el. A fovea infraspinati közvetlenül a caput humeri alatt található anterior helyzetú, sekély bemélyedés. A tuberositas posterior nagy kiterjedésú, határozott kiemelkedést képez a diaphysis középmagasságában. A diaphysis oldalnézetből a tuberositas posterior felett kis mértékben medialis irányban 
hajlott. A crista distalis a humerus középvonalától posterior helyzetú, így a facies radialis antero-posterior kiterjedése nagyobb, mint a facies ulnarisé. A facies olecranica jól fejlett, és erôteljes kiterjedésú. A felkarcsont arányait figyelembe véve, a taxon testhossza kb. 2,5 m lehetett.

Összehasonlítás a Középsó- és a Keleti-Paratethys területéról elókerült leletekkel: A Cetotheriidae indet. egy szintén kistermetú sziláscet felkarcsontja. Valamennyi leírt példánytól egyértelmúen elkülöníthetô morfológiai karaktereiben, illetve mérete alapján is. Új fajként történő leírásához további példányok elôkerülése szükséges. A példány valószínúleg szarmata (esetleg badeni) üledékből halmozódott át.

\section{Következtetések}

A danitzpusztai homokbányából három Mysticeti taxont lehetett elkülöníteni humerus alapján.

Ezen kívül több juvenilis humerus diaphysis és proximalis epiphysis is ismert, besorolásuk a három taxon valamelyikébe nem lehetséges, a morfológiai jegyek hiányossága miatt.

Az összehasonlítások után megállapítható, hogy páratlanul kistermetú bálnák is éltek a Pannon-medence középsô-miocén tengerében, ahol a kisebbek 2-2,5 m, a nagyobbak 2,5-3,5 m közötti testhosszúságúak lehettek. A területről begyújtött sziláscetcsigolyák is jól tükrözik e mérethatárokat.

A cf. Cetotherium priscum EICHWALD, 1840 bálnafajba sorolt humerusok Danitzpusztán, és a kárpáti régióban a leggyakoribb elemek, melyek nagyban bővítik ismereteinket a fajon belüli méretbeli és morfológiai variációkra vonatkozólag.

A Macrochirifer brachyspondylus (BRANDT, 1873), a Mesocetus (?) brachyspondylus (BRANDT, 1873), a bécsimedencei NHMW 1874 V.29. leltári számú (publikálatlan), a samobori (GORJANOviĆ-KRAMBERGER, 1884), valamint a pécs-vasasi (publikálatlan, MÁFI V.18393/4) példányok a revízió szerint, a danitzpusztai cf. Cetotherium priscumba sorolt felkarcsontokkal azonos fajt képviselnek.

A ,Cetotherium” aff. maicopicum taxonba sorolt példányok világviszonylatban az eddigi legkisebb felkarcsontleletek, melyek morfológiailag a "Cetotherium” maicopicum SPASSKI, 1951 fajjal mutatnak egyezést.

A Cetotheriidae indet. humerusnak a hasonló leletekkel való összehasonlítás alapján, nem sikerült a pontosabb besorolása. A példány egy kistermetú valószínúleg új faj lehet, melynek a geológiai kora szarmata, de nem zárható ki az elókerülési körülményei miatt, a badeniből történő áthalmozódása sem.

A „Cetotherium” aff. maicopicum, és a Cetotheriidae indet. taxonba sorolt humerusok új fajként történő leírása további kutatásokat igényel.

\section{Köszönetnyilvánítás}

Köszönetemet fejezem ki a Gyújteményi Osztály valamint az Országos Földtani Szakkönyvtár (MBFSZ) munkatársainak a kutatásomhoz nyújtott segítségükért. A magángyújtók Christian CheFdeville, Evanics Zoltán, KANIZSAI László, MáJer Tibor, Molnár Roland, és OrbáN Zoltán feldolgozásra átadott, vagy a magángyújteményében megmutatott leletanyagát köszönöm. A Quartz Kft-nek a bányában történő kutatási engedélyt köszönöm. Külön köszönetet mondok DócZI-SZABÓ Noéminek, GASPARIK Mihálynak, KAZÁr Emesének, Kordos Lászlónak, MISETA Ritának, MolNár Bélának, és SELMECZI Ildikónak. Köszönettel tartozom lektoraimnak SEBE Krisztinának és SZENTESI Zoltánnak az alapos, minden részletre kiterjedő lektori munkájukért, valamint SzTANó Orsolyának és DULAI Alfrédnak hasznos tanácsaikért.

\section{Irodalom - References}

BALSAmo-Crivelli C. G. 1842: Memoria per servire all'illustrazione dei grandi Mammiferi fossili esistenti nell'I. R. Gabinetto di S. Teresa in Milano. - Giornale dell'I. R. Istituto Lombardo di Scienze, Letteratura ed Arti e Biblioteca Italia-89 na compilata da varj dotti nazionali e stranieri. Tomo III, 297-319.

BÄUML, E. 1933: Untersuchungen über die fossilen Wale des Wiener Beckens anhand der Humeri. - Maturahausarbeit, Mädchenrealgymnasium Albertgasse, Wien. - Handschriften in der Geologisch-Paläontologischen Abteilung der Naturhistorischen Museums Wien, $26 \mathrm{p}$.

BENKE, H. 1993: Investigations on the osteology and the functional morphology of the flipper of whales and dolphins (Cetacea). Investigations on Cetacea 24, 9-252.

Bouetel, V. \& Muizon, C. 2006: The anatomy and relationships of Piscobalaena nana (Cetacea, Mysticeti), a Cetotheriidae s.s. from the early Pliocene of Peru. - Geodiversitas 28/2, 319-395.

BRANDT, J. F. 1843: De cetotherio, novo balaenarum familiae genre in Rossia Meridionali ante aliquot annos effoso. — Bulletin de La Classe Physico-Mathématique de L'Académie Impérial des Sciences de St. Pétersbourg 1/10-12, 145-148.

BRANDT, J. F. 1871: Bericht uber den Fortgang meiner Studien uber di Cetaceen, welche das grosse zur Tertiarzeit von Mitteleuropa bis Centralasien hinein ausgedehnte Meeresbechen bevolkerten. — Bulletin de l'Academie Imperiale de St. Petersbourg 16, 563-566.

BRANDT, J. F. 1872a: Bemerkungen über die untergegangenen Bartenwale (Balaenoiden), deren Reste bisher im Wiener Becken gefunden wurden. - Sitzungsberichte der kaiserlichen Akademie der Wissenschaften, I. Abtheilung 65, 258-264. 
BRANDT, J. F. 1872b: Über eine neue Classification der Bartenwale (Balaenoidea) mit Berücksichtigungder untergegangenen Gattungen derselben. - Bulletin de l'Académie Impérialedes Sciences de St. Pétersbourg 17, 113-124.

BRANDT, J. F. 1873: Untersuchungen über die fossilen und subfossilen Cetaceen Europa's. — Mémoires de l'Académie Impériale des Sciences de St. Pétersbourg 7/20/1, 1-372, 34 pls. https://doi.org/10.5962/bhl.title.39524

BRANDT, J. F. 1874: Ergänzungen zu den Fossilen Cetaceen Europa's. — Mémoires de L'Academie Impériale des Sciences de St. Pétersbourg 7/21/6, 54 p. https://doi.org/10.5962/bhl.title.39688

Czyžewska, T. \& RyzIEwICZ, Z. 1976: Pinocetus polonicus gen. n. sp. n. (Cetacea) from the Miocene limestones of Pinczow, Poland. Palaeontologica Polonica 21/3, 259-298.

Dombrovskis, B 1927: Deux trouvailles de restes de Cétacés fossiles du genre Pachyacanthus Brndt. dans le Caucase. — Travaux du Musée Géologique prés l'Académie des Sciences de l'URSS, 2, 1-39, pl 1-2 (oroszul)

Dooley, A. C., Fraser, N. C. \&. Luo, Z. 2004: The earliest known member of the rorqual-gray whale clade (Mammalia, Cetacea). Journal of Vertebrate Paleontology 24/2, 453-463.

EICHWALD, C. E. 1840: Beschreibung einiger Knochen des Ziphius priscus. — Die Urwelt Russlands $2,25-53$.

Eichwald, C. E. 1853: Lethaea Rossica ou Paléontologie de la Russie. — Stuttgart 332-340.

Gol'din, P. \& Startsev, D. 2014: Brandtocetus, a new genus of baleen whales (Cetacea, Cetotheriidae) from the late Miocene of Crimea, Ukraine. — Journal of Vertebrate Paleontology 34/2, 419-433. https://doi.org/10.1080/02724634.2013.799482

Gol'din, P., Startsev, D \& KrakhmalnayA, T. 2014: The anatomy of the Late Miocene baleen whale Cetotherium riabinini from Ukraine. - Acta Palaeontologica Polonica 59/4, 795-814. https://doi.org/10.4202/app.2012.0107

Gol'din, P. \& Startsev, D. 2016: A systematic review of cetothere baleen whales (Cetacea, Cetotheriidae) from the Late Miocene of Crimea and Caucasus, with a new genus. _ Papers in Paleontology 2/4, 1-20. https://doi.org/10.1002/spp2.1066

Gorjanović-Kramberger, D. 1884: Fosilni sisari Hrvatske, Slavonije i Dalmacije. — Rad Jugoslavenske Akademije Znanosti i Umjetnosti, 69, 60-93, Pl. 1-2.

HАмPE, O. 1996: Ein artikuliertes Bartenwalskelett aus dem Neogen (? Uedem-Schichten, Obermiozän) der Neiederrheinischen Bucht (NW-Deutschland) und seine systematische Stellung innerhalb der Mysticeti (Mammalia: Cetacea). — Decheniana Beiheft 33, 175.

HÁMOR G. 1981: Pécs, Danitz-pusztai homokbánya (alsó-pannóniai). — In: JÁMBOR Á. (szerk.): Földtani kirándulások a magyarországi molassz területeken. Magyarország molassz képződményei. A szocialista országok tudományos akadémiái IX. P. K. 3. 3. munkacsoportjának magyarországi ülése 1981 októberében. A Magyar Állami Földtani Intézet alkalmi kiadványa 143. Magyar Állami Földtani Intézet, Budapest, 128-130.

HÁMOR G. 2001: A Kárpát-medence miocén ősföldrajza. Magyarázó a Kárpát-medence miocén ősföldrajzi fáciestérképéhez 1:3 000 000. — MÁFI, térképmagyarázói, Budapest 66 p, 4 térkép, I-VII. melléklet.

HofSTEIN, I. D. 1948: Pachyostosis in fossil whales. — Zbirnyk Prats Z Paleontologii I Stratygrafii, Instytut Geologichnych Nauk URSR 1/2, 65-75.

KADIČ O. 1907: Mesocetus hungaricus Kadić. Egy új balaenopterida-faj a borbolyai mioczén rétegekből. — A Magyar Királyi Földtani Intézet Évkönyve, 16/2, 19-86.

KAZÁr E. 2003: Miocén fogascet-leletek (Cetacea: Odontoceti) a Kárpát-medencében. [Miocene toothed whales (Cetacea: Odontoceti) in the Carpathian Basin.] — Unpublished Ph. D. dissertation, Eötvös LorándUniversity, Budapest, 344 p. [In Hungarian, with abstract in English.]

KAZÁR E. 2005: A new kentriodontid (Cetacea: Delphinoidea) from the middle Miocene of Hungary. — Mitteilungen aus dem Museum für Naturkunde in Berlin, Geowissenschaftliche Reihe 8, 53-73. https://doi.org/10.5194/fr-8-53-2005

KAZÁr E. 2006a: Sophianaecetus, a replacement name for Mediocris (Cetacea: Delphinoidea: Kentriodontidae). — Fossil Record 9, 260. https://doi.org/10.1002/mmng.200600013

KAZÁr E. 2006b: Odontocete periotics (Mammalia: Cetacea) from the Carpathian Basin, Middle Miocene (Badenian and Sarmatian Stages), including the Vienna Basin, Austria. — Beiträge zur Paläontologie 30, 269-292.

KAZÁR, E. 2010: Revision of the genus Pachyacanthus Brandt, 1871 (Mammalia: Cetacea: Odontoceti). — Annalen des Naturhistorischen Museums in Wien, Serie A 112, 537-568.

KAZÁR, E. \& BoHASKA, D. J. 2008: Toothed whale (Mammalia: Cetacea: Odontoceti) limb bones of the Lee Creek Mine, North Carolina. — In: Ray, C. E., Bohaska, D. J., Koretsky, I. A., WARD, L. W. \& Barnes, L. G. (eds): Geology and Paleontology of the Lee Creek Mine, North Carolina IV. — Virginia Museum of Natural History Special Publication 14, 271-324

KaZÁr, E. \& GRIGOREscu, D. 2005: Revision of Sarmatodelphis moldavicus Kirpichnikov, 1954 (Cetacea: Delphinoidea), from the Miocene of Kishinev, Republic of Modavia. — Journal of Vertebrate Paleontology 25/4, 929-935. https://doi.org/10.1671/02724634(2005)025[0929:rosmkc]2.0.co;2

KAZÁr, E. \& VENCEL, M. 2003: Kentriodontid remains (Cetacea: Odontoceti) from the middle Miocene of Bihor County, Romania. — Nyphaea Folia naturae Bihariae 30, 39-66.

KazÁr E., Kordos L. \& Szónoky M. 2007: Danitz-puszta. — In: PÁlfy J., Pazonyi P. (szerk.): Őslénytani kirándulások Magyarországon és Erdélyben. — Hantken kiadó, Budapest, pp. 131-132.

KAZÁr, E., Vremir, M. \& CodreA, V. 2004: Dolphin remains (Cetacea: Odontoceti) from the middle Miocene of Cluj-Napoca, Romania. - Acta Paleontologica Romanie 4, 179-189.

KellogG, R. 1929: A new cetothere from southern California. — University of California Publications in Geological Sciences 18/15, 449-457.

KellogG, R. 1931: Pelagic mammals from the Temblor formation of the Kern River region, California. - Proceedings of the California Academy of Sciences, 19/12, 217-397. 
KellogG, R. 1965: Fossil Marine Mammals from the Miocene Calvert Formation of Maryland and Virginia, parts 1-2. — Bulletin of the United States National Museum, 247, 63 p., 32 plates, 31 figures.

KellogG, R. 1966: Fossil Marine Mammals from the Miocene Calvert Formation of Maryland and Virginia, parts 3-4. — Bulletin of the United States National Museum, 247, 65-101, figures 32-38, plates 33-45.

KellogG, R. 1968: Fossil Marine Mammals from the Miocene Calvert Formation of Maryland and Virginia, parts 5-8. - Bulletin of the United States National Museum, 247, 103-201, figures 39-98.

KelloGG, R. 1969: Cetothere skeletons from the Miocene Choptank Formation of Maryland and Virginia. — Bulletin of the United States National Museum 294, 40 p. https://doi.org/10.5479/si.03629236.294.1

KonRÁd Gy., SEBE K. 2010: Fiatal tektonikai jelenségek új észlelései a Nyugat-Mecsekben és környezetében. — Földtani Közlöny 140/2, 445-468.

Konrád Gy., Kordos L., Sebe K. 2010: Danitz-pusztai homokbánya, Pécs, Mecsek. Ôslényvadászat a Pannon-tó peremén. — In: HaAS J. (szerk.): A múlt ösvényein. Magyarhoni Földtani Társulat, Budapest, 160-164. (195p.)

KoRDOs L. 1978: Magyarország eocén, oligocén és miocén ősgerinces lelőhelyei. — Magyar Állami Földtani Intézet Évi Jelentése az. 1976. évról, 291-295.

KoRDOs L. 1992: Magyarország harmad-és negyedidôszaki emlósfaunájának fejlódése és biokronológiája. — Akadémiai doktori értekezés, Budapest. 104 p. + függelék.

Kordos L. \& Solt P. 1984: A magyarországi miocén tengeri gerinces faunaszintek vázlata. — Magyar Állami Földtani Intézet Évi Jelentése az 1982. évról, 347-354.

KreTzor M. 1955: A hazai emlősállatok fejlődéstörténete. - Útmutató a TIT elóadói számára. Társadalom- és Természettudományi Ismeretterjesztô Társulat, Budapest, 23 p.

MagYar I. 2010. A Pannon-medence ösföldrajza és környezeti viszonyai a késố miocénben. — SZTE TTIK Földrajzi és Földtani Tanszékcsoport, Geolitera, Szeged, 140 p.

Mchedlidze, G. A. 1964: Fossil Cetacea of the Caucasus. — Washington, D.C Smithsonian Institution Libraries and National Science Foundation $144 \mathrm{p}$.

MCHEDLIDZE, G. A. 1970: Nekotorye obshchie cherty istorii kitoobraznykh. Chast' 1. (Some features of the historical development of the Cetacea, Part 1). - Akademia Nauk Gruzinskoi S.S.R., Institut Paleobiologii. Metsniereba Publishers, Tbilisi 112 p, 6 pls. [Oroszul, angol összefoglalással.]

MchedLIDZE, G. A. 1984: Fossilized Whale from the Miocene Deposits in the Environs of the Village of Otradnaya. — Akademia Nauk Gruzinskoi S.S.R., Institut Paleobiologii. Metsniereba Tbilisi 64 p. (oroszul)

Nordmann, A. 1860: Palaeontologie Südrusslands I-IV. - H. C. Friis, Helsingfors 360 p. \& Atlas.

Packard, E. L. \& Kellogg, R 1934: A new cetothere from the Miocene Astoria Formation of Newport, Oregon. - Contributions to Palaeontology Carnegie Institution of Washington 3-62.

PAVŠIČ, J. \& MikUŽ, V. 1996: The baleen whale (Balaenoptera acutorostrata cuvierii) from Miocene beds near Benedikt in Slovenske Gorice, Slovenia. - Razprave 37/4, 85-97.

PIA, J. 1937: Von den Walen des Wiener Miozäns. Kurze Übersicht der Kenntnisse und Fragen. — Mitteilungen der Geologischen Gesellschaft in Wien 29, 357-428.

PiA, J. \& SickenberG, O. 1934: Katalog der in den österreichischen Sammlungen befindlichen Säugetierreste des Jungtertiärs Österreichs und der Randgebiete. —Denkschriften des Naturhistorischen Museums in Wien 4, 544 p.

PILlERI, G. 1986: Beobachtungen an Den Fossilen Cetaceen des Kaukasus. — Hirnanatomisches Institut der Universität Bern (Schweiz) 40 p, 22 Abb., 26 Taf.

PILlerI, G. 1989: Balaenoptera siberi, ein neuer spatmiozaner bartenwal aus der Pisco-formation Perus. — Beitrage zur Palaontologie der Cetaceen Perus 65-84.

Riabinin, A. N. 1934: New contributions to the osteology of Cetotherium mayeri Brandt, from the Upper Sarmatian of the North Caucasus. - Transactions of the United Geological and Prospecting Service of USSR 350, $15 \mathrm{p}$.

Simionescu, I. 1931: Mamifere marine din Sarmaticul dela Balcic. —-Academia Română Memoriile Sectiunții Ştiințifice (Bucharest) 3/8, 145-157.

Sebe K., Csillag G., Dulai A., Gasparik M., Magyar I., Selmeczi I., Szabó M., Sztanó O. \& Szuromi-Korecz A. 2015: Neogene stratigraphy in the Mecsek region. - Neogene of the Paratethyan Region. $6^{\text {th }}$ Workshop on the Neogene of Central and South-Eastern Europe. An RCMNS Interim Colloquium. Programme, Abstracts, Field Trip Guidebook. Orfü. Magyarhoni Földtani Társulat, Budapest, pp. 102-124. ISBN 978-963-8221-57-5

SPASSKI, P. I. 1951: Ostaki iskopaemykh kitoobraznykh iz sarmatskikh otlozhenii okrestnostei Derbent. — Trudy estestvenno-isroricheskogo muzia 8, 188-226.

SPASSKI, P. I. 1954: Finds of bones of upper tertiary mammals in the neighbourhood of Derbent. — Trudy Estestvenno Istoricheskogo Muzeia im G. Zabadi, Akademiya Nauk Azerbaidzhanskoi S.S.R. Baku 8, 188-226 (oroszul)

Stefanović, I. 2010: Note on the first fossil remains of a whale from northern Bosnia. - Annales Geologiques de la Peninsule Balkanique 71, 127-137. https://doi.org/10.2298/gabp1071127s

Tarasenko, K. K. 2014: New Genera of Baleen Whales (Cetacea, Mammalia) from the Miocene of the Northern Caucasus and Ciscaucasia: 3. Zygiocetus gen. nov. (Middle Sarmatian, Adygea). — Paleontological Journal 48/5, 551-562. https://doi:10.1134/ S0031030114050116

TARAsenko, K. K. \& Lopatin, A. V. 2012a: New Baleen Whale Genera (Cetacea, Mammalia) from the Miocene of the Northern Caucasus and Ciscaucasia: 1. Kurdalagonus gen. nov. from the Middle-Late Sarmatian of Adygea. — Paleontological Journal 46/5, 531-542. https://doi:10.1134/S0031030112050115 
Tarasenko, K. K. \& Lopatin, A. V. 2012b: New Baleen Whale Genera (Cetacea, Mammalia) from the Miocene of the Northern Caucasus and Ciscaucasia: 2. Vampalus gen. nov. from the Middle-Late Miocene of Chechnya and Krasnodar Region. - Paleontological Journal 46/6, 620-629. https://doi.org/10.1134/s003103011206010x

Van Beneden, M. P. J. 1882: Description des Ossements Fossiles des Environs D’Anvers Troisieme Partie: Cetaces Genera: Megaptera, Balenoptera, Burtinopsis \& Erpetocetus. — Annales du Musee Royal D’Histoire Naturelle de Belgique, Brüssel 7, 90p, 3Abb., Atlas m. 70 Taf.

Van Beneden, M. P. J. 1885: Description des Ossements Fossiles des Environs D’Anvers Quatrième Partie: Plesiocetus. — Annales du Musee Royal D'Histoire Naturelle de Belgique 9, 40 p, 1 Abb., Atlas m. 30 Taf.

VAn Beneden, M. P. J. 1886: Description des Ossements Fossiles des Environs D’Anvers Troisieme Partie: Cetaces Genera: Amphicetus, Heterocetus, Mesocetus, Idiocetus et Isocetus. — Annales du Musee Royal D'Histoire Naturelle de Belgique, Brüssel 13, 139 p, 1 Abb., Atlas m. 75 Taf.

Kézirat beérkezett: 2017. 07. 31. 


\section{I. tábla - Plate I}
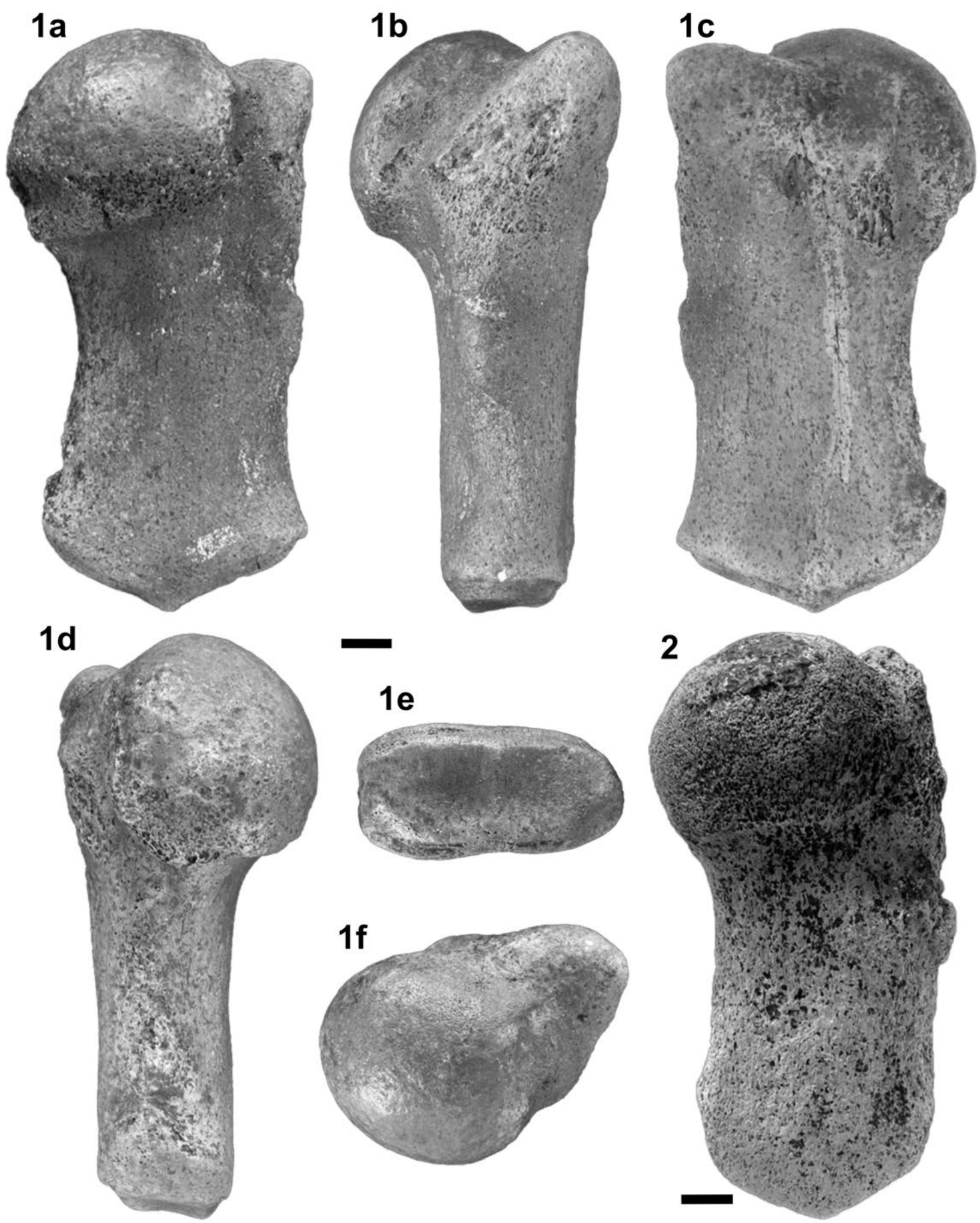

I. tábla cf. Cetotherium priscum (EICHWALD, 1840) Pécs, Danitzpusztáról. 1a-f: MÁFI V.09.319.1 (MÁFI V.28768) jobb humerus 1a: lateralis, 1b: anterior, 1c: medialis, 1d: posterior, 1e: ventralis, és 1f: dorsalis nézetben; 2: MÁFI V.23219 jobb humerus, lateralis nézetben. Méretarány: $10 \mathrm{~mm}$

Plate I. $c f$. Cetotherium priscum (EICHWALD, 1840) from Pécs, Danitzpuszta. la-f: MÁFI V.09.319.1 (MÁFI V.28768) right humerus in la: lateral, 1b: anterior, 1c: medial, 1d: posterior, 1e: ventral, and 1f: dorsal views; 2: MÁFI V.23219 right humerus, in lateral view. Scale bar equals: $10 \mathrm{~mm}$ 


\section{II. tábla - Plate II}
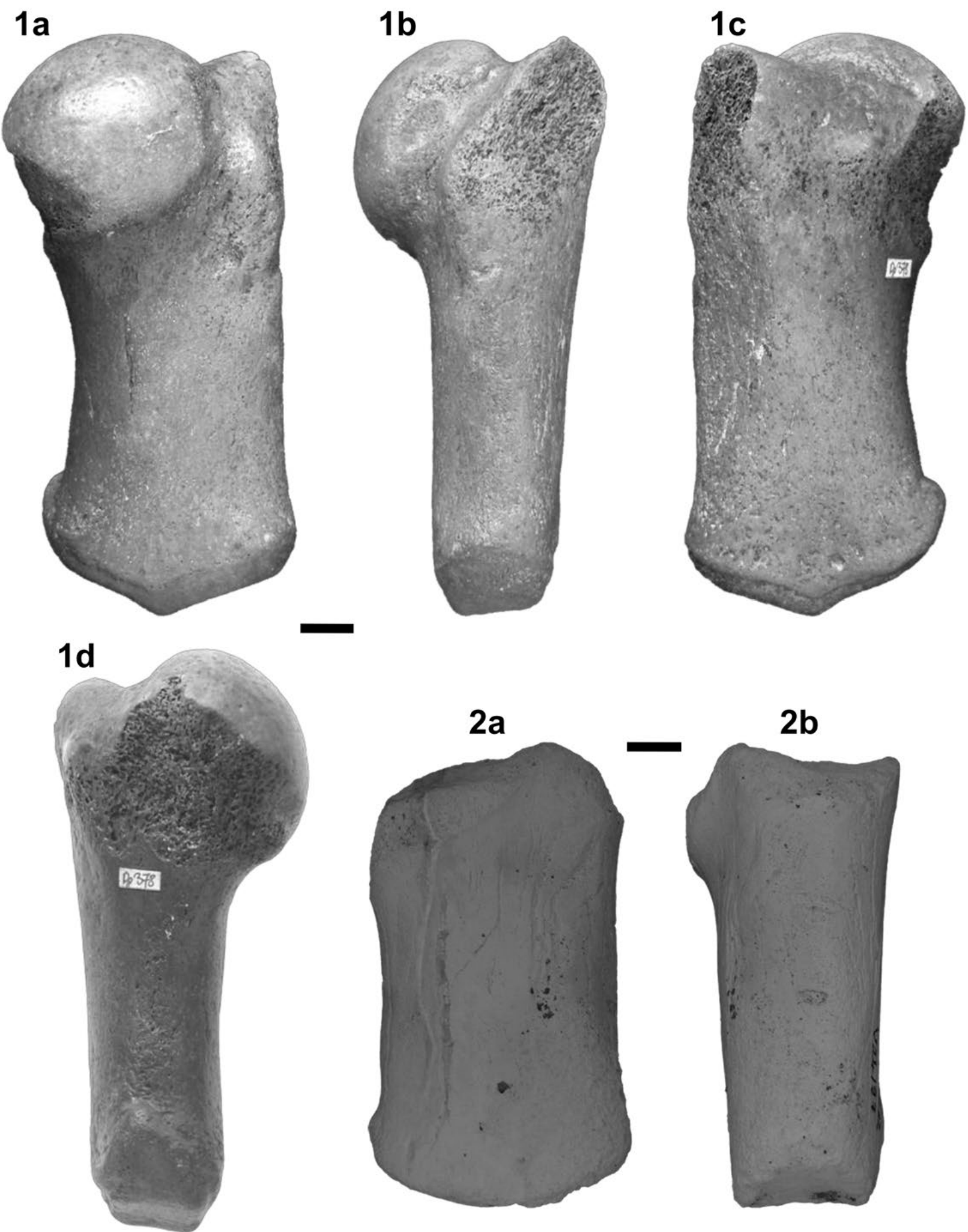

II. tábla cf. Cetotherium priscum (EICHWALD, 1840) Pécs, Danitzpusztáról. 1a-d: MÁFI V.09.274.1 (MÁFI V.28723) jobb humerus 1a: lateralis, 1b: anterior, 1c: medialis, és 1d: posterior nézetben; 2a-b: MÁFI V.24197, jobb humerus diaphysis, 2a: lateralis, és 2b: anterior nézetben; Méretarány: $10 \mathrm{~mm}$

Plate II. cf. Cetotherium priscum (EICHWALD, 1840) from Pécs, Danitzpuszta. 1a-d: MÁFI V.09.274.1 (MÁFI V.28723) right humerus in 1a: lateral, 1b: anterior, 1c: medial and 1d: posterior views; 2a-b: MÁFI V.24197, right humerus diaphysis, in 2a: lateral, and 2b: anterior views; Scale bar equals: $10 \mathrm{~mm}$ 


\section{III. tábla - Plate III}
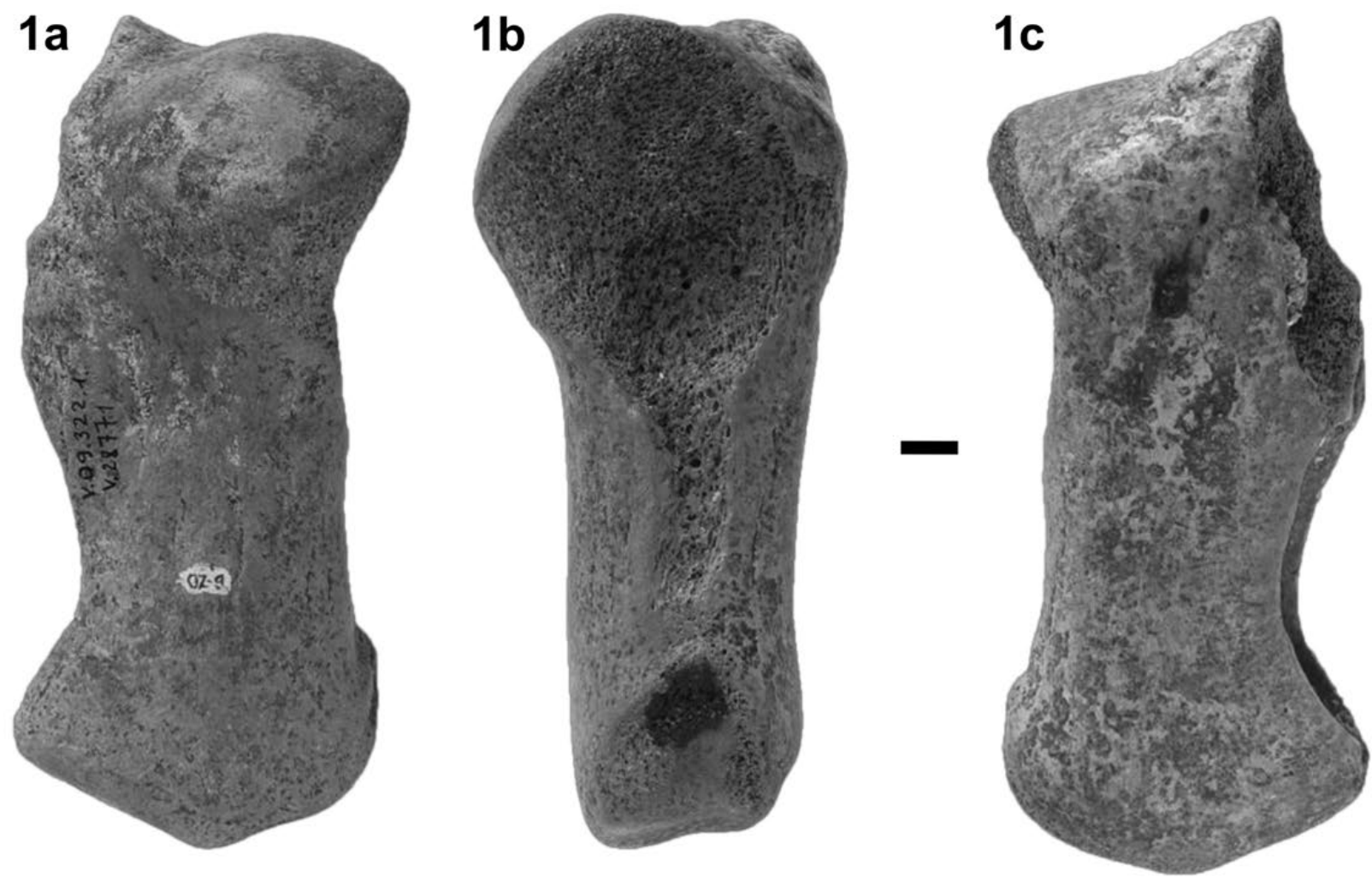

$2 \mathrm{a}$

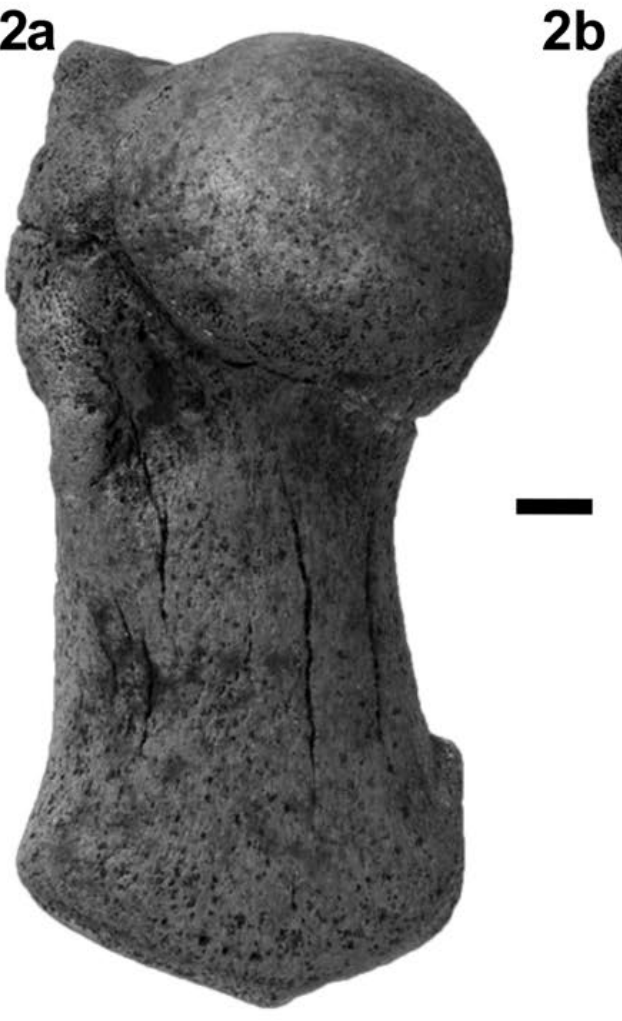

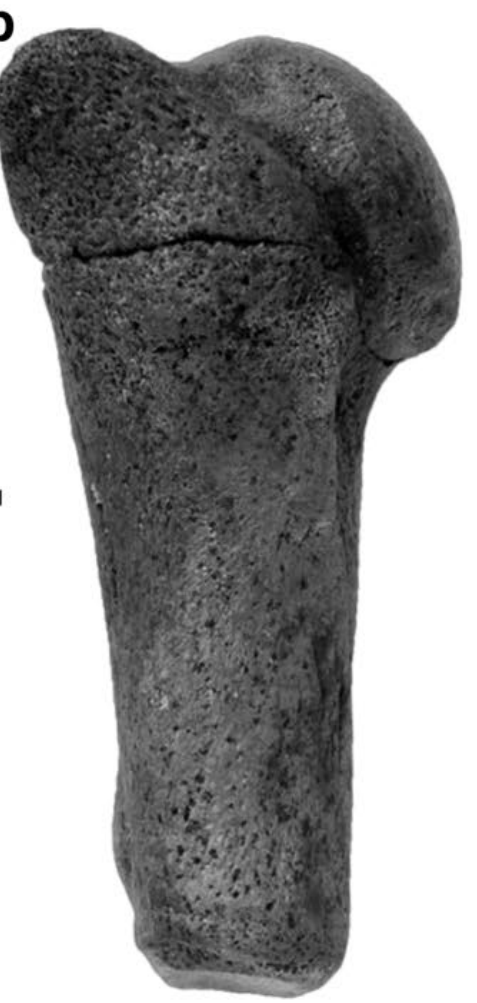

2c

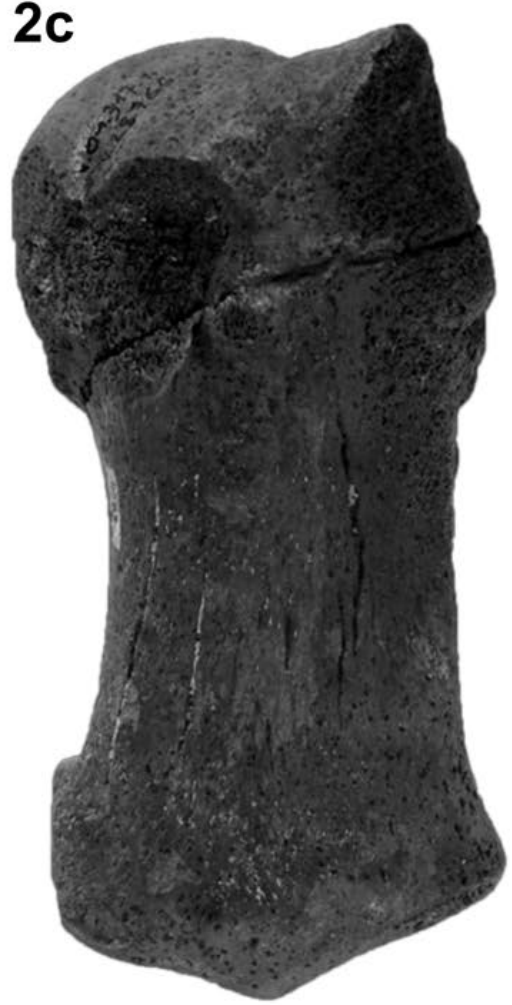

III. tábla cf. Cetotherium priscum (EIcHWALD, 1840) Pécs, Danitzpusztáról. 1a-c: MÁFI V.09.322.1 (MÁFI V.28771) bal humerus 1a: lateralis, 1b: posterior, és 1c: medialis nézetben; 2a-c: MÁFI V.09.317.1 (MÁFI V.28766) bal humerus, 2a: lateralis, 2b: anterior, 2c: medialis nézetben. Méretarány: $10 \mathrm{~mm}$

Plate III. cf. Cetotherium priscum (EICHWALD, 1840) from Pécs, Danitzpuszta. 1a-c: MÁFI V.09.322.1 (MÁFI V.28771) left humerus, in la: lateral, 1b: posterior, and 1c: medial views; 2a-c: MÁFI V.09.317.1 (MÁFI V.28766) left humerus in 2a: lateral, 2b: anterior, and 2c: medial views. Scale bar equals: $10 \mathrm{~mm}$ 
IV. tábla - Plate IV
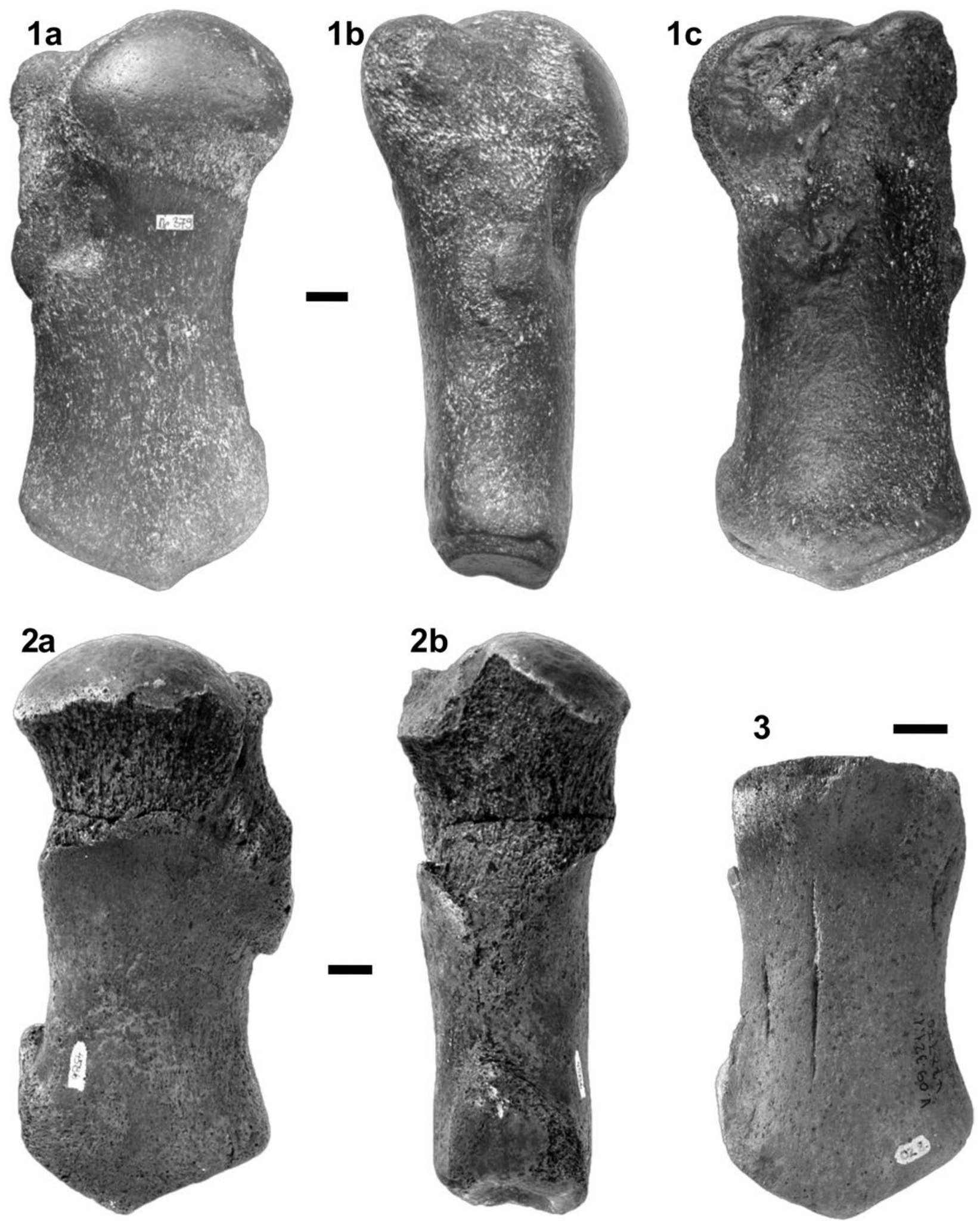

IV. tábla cf. Cetotherium priscum (EICHWALD, 1840) Pécs, Danitzpusztáról. 1a-c: Dp.379 bal humerus 1a: lateralis, 1b: anterior, és 1c: medialis nézetben; 2a-b: MÁFI V.09.316.1 (MÁFI V.28765) jobb humerus, 2a: lateralis, és 2b: posterior nézetben; 3: MÁFI V.09.321.1 (MÁFI V.28770) jobb humerus distalis fragmentum, lateralis nézetben. Méretarány: $10 \mathrm{~mm}$

Plate IV. $c f$. Cetotherium priscum (EICHWALD, 1840) from Pécs, Danitzpuszta. 1a-c: Dp.379 left humerus in 1a: lateral, 1b: anterior, and 1c: medial views; 2a-b: MÁFI V.09.316.1 (MÁFI V.28765) right humerus in 2a: lateral, and 2b: posterior views; 3: MÁFI V.09.321.1 (MÁFI V.28770) right humerus distal fragment, in lateral view. Scale bar equals: $10 \mathrm{~mm}$ 


\section{V. tábla - Plate V}

\section{$1 \mathrm{a}$}

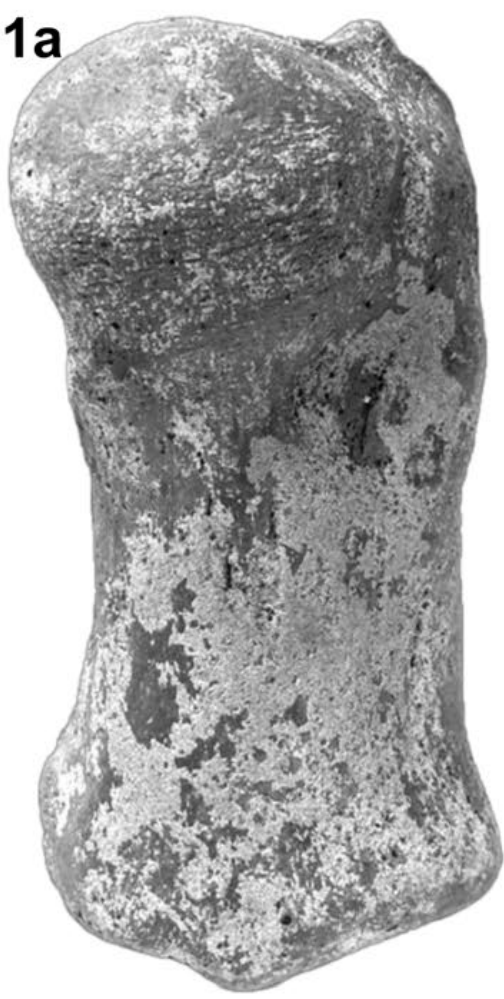

\section{2}

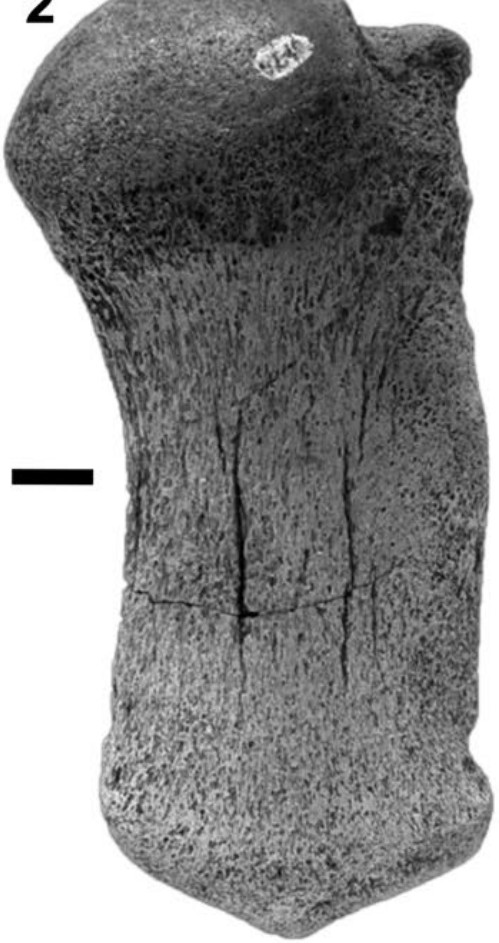

$1 \mathrm{~b}$
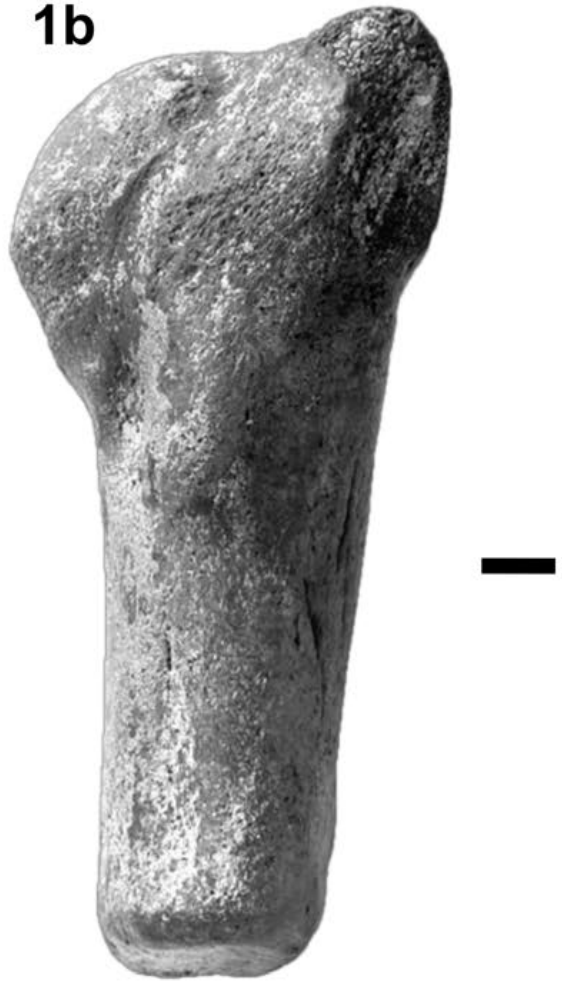

1c

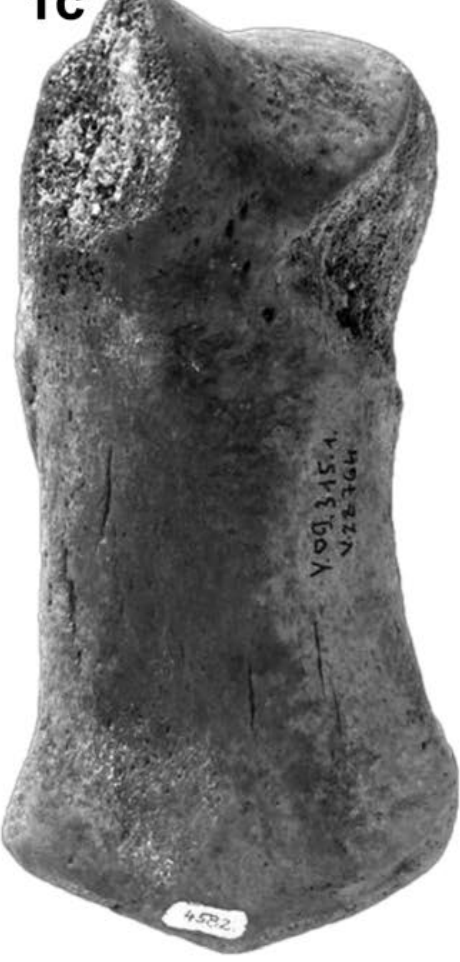

$3 d$

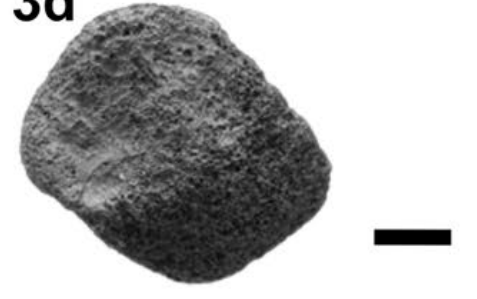

$3 a$

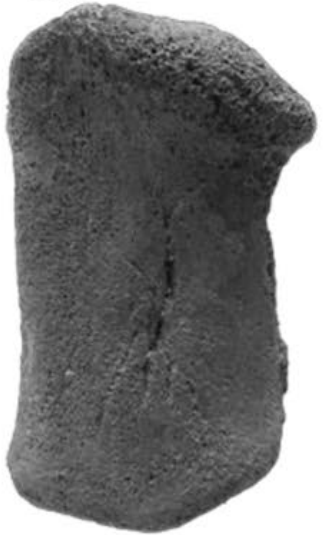

\section{$3 b$}

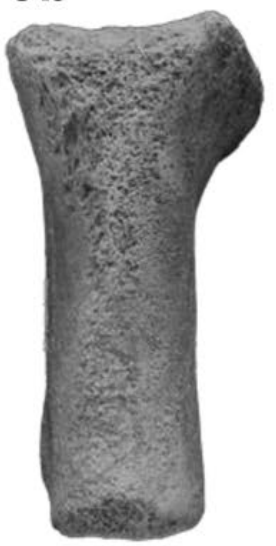

$3 e$

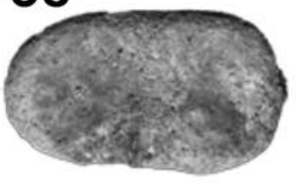

$3 c$

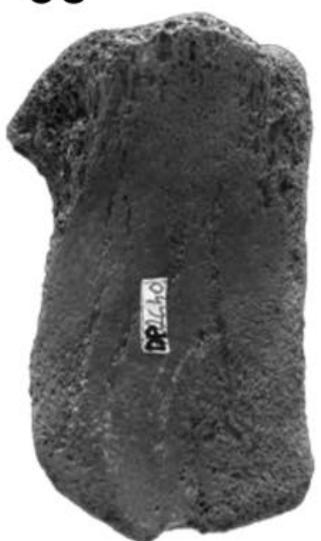

V. tábla cf. Cetotherium priscum (EICHWALD, 1840) Pécs, Danitzpusztáról. 1a-c: MÁFI V.09.315.1 (MÁFI V.28764) jobb humerus 1a: lateralis, 1b: anterior, és 1c: medialis nézetben; 2: MÁFI V.09.323.1 (MÁFI V.28772) jobb humerus lateralis nézetben; 3a-e: Dp.2640 bal humerus diaphysis 3a: lateralis, 3b: anterior, 3c: medialis, 3d: dorsalis, és 3e:ventralis nézetben; Méretarány: $10 \mathrm{~mm}$

Plate V. cf. Cetotherium priscum (EICHWALD, 1840) from Pécs, Danitzpuszta. la-c: MÁFI V.09.315.1 (MÁFI V.28764) right humerus in la: lateral, 1b: anterior, and 1c: medial views; 2: MÁFI V.09.323.1 (MÁFI V.28772) right humerus in lateral view; $3 a-e: D p .2640$ left humerus diaphysis, in $3 a$ : lateral, $3 \mathrm{~b}$ : anterior, $3 \mathrm{c}$ : medial, $3 \mathrm{~d}$ : dorsal, and $3 \mathrm{e}$ : ventral views. Scale bar equals: $10 \mathrm{~mm}$ 


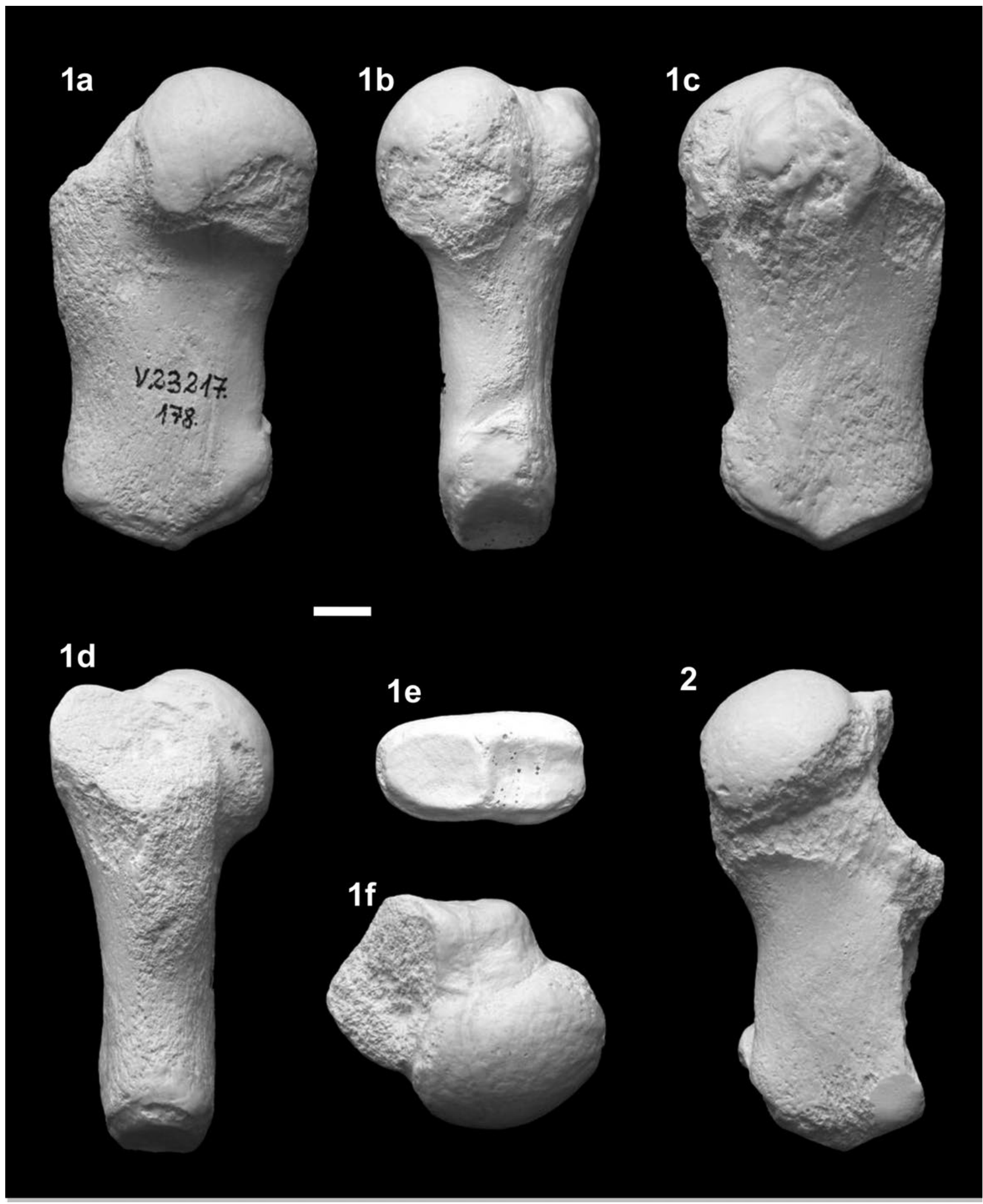

VI. tábla „Cetotherium” aff. maicopicum Pécs-Danitzpusztáról. 1a-f: MÁFI V.23217 bal humerus (gipszmásolat) 1a: lateralis, 1b: posterior, 1c: medialis, 1d: anterior, 1e: ventralis, és 1f: dorsalis nézetben; 2: MÁFI V.23216 jobb humerus (gipszmásolat), lateralis nézetben. Méretarány: $10 \mathrm{~mm}$

Plate VI. "Cetotherium” aff. maicopicum from Pécs-Danitzpuszta. 1a-f: MÁFI V.23217, left humerus (cast) in la: lateral, 1b: posterior, 1c: medial, 1d: anterior, le: ventral, and 1f: dorsal views; 2: MÁFI V.23216 right humerus (cast), lateral view. Scale bar equals: $10 \mathrm{~mm}$ 


\section{VII. tábla - Plate VII}
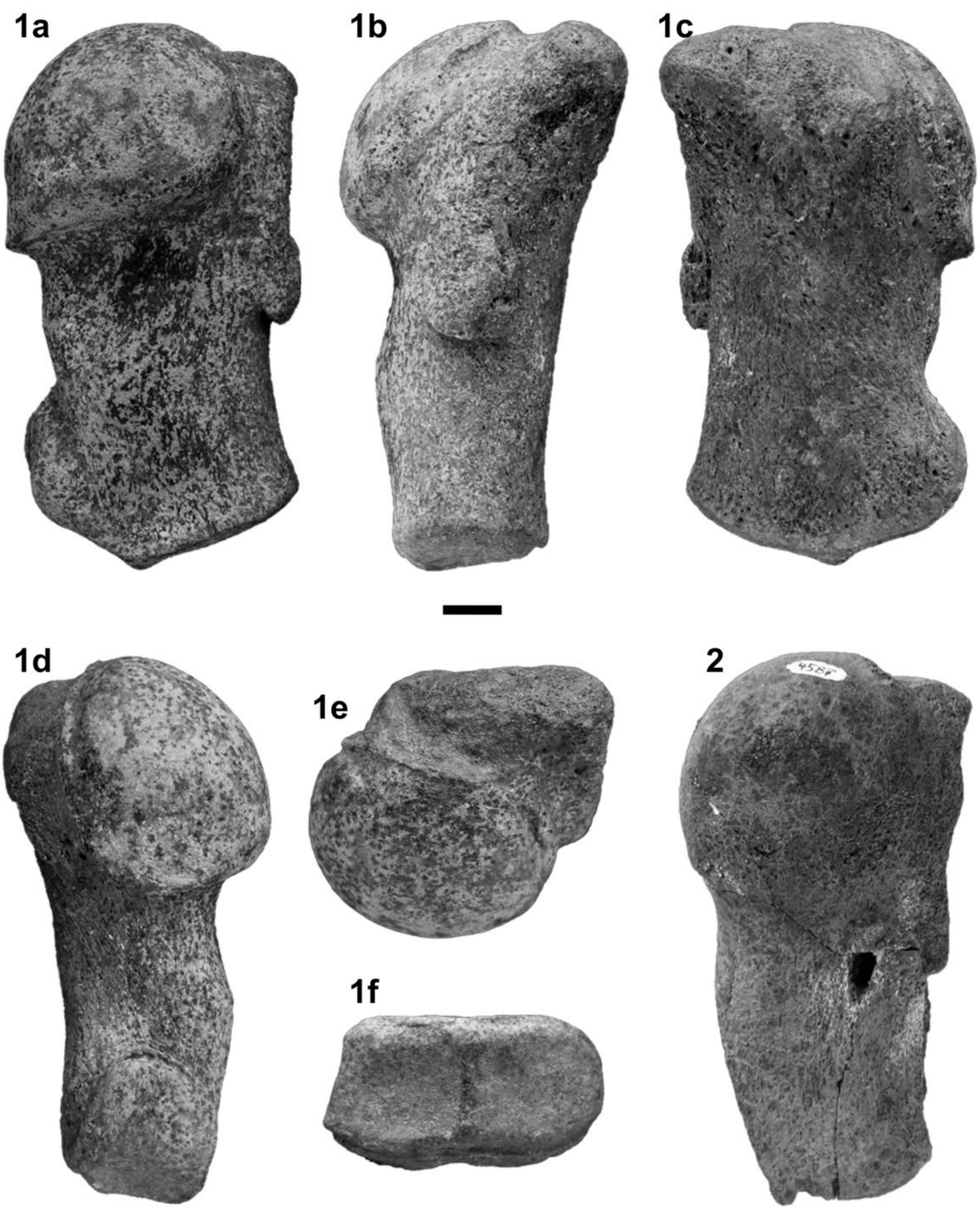

VII. tábla Cetotheriidae indet. Pécs, Danitzpusztáról. 1a-f: MÁFI V.24188 jobb humerus, 1a: lateralis, 1b: anterior, 1c: medialis, 1d: posterior, 1e: dorsalis, és 1f: ventralis nézetben; 2: cf. Cetotherium priscum EICHWALD, 1840, MÁFI V.09.313.1 (MÁFI V.28762) jobb humerus proximalis fragmentum, lateralis nézetben. Méretarány: $10 \mathrm{~mm}$

Plate VII. Cetotheriidae indet. from Pécs, Danitzpuszta. 1a-f: MÁFI V.24188 right humerus in 1a: lateral, 1b: anterior, 1c: medial, 1d: posterior, 1e: dorsal, and 1f: ventral views; 2: cf. Cetotherium priscum EICHWALD, 1840, MÁFI V.09.313.1 (MÁFI V.28762) right humerus proximal fragment, in lateral view. Scale bar equals: $10 \mathrm{~mm}$ 